\title{
Porezni klin u Hrvatskoj, Italiji, Irskoj, Nizozemskoj i Španjolskoj
}

\section{Cundić, Maja}

Source / Izvornik: Odabrani prijevodi, 2016, 7, 1 - 33

Journal article, Published version

Rad u časopisu, Objavljena verzija rada (izdavačev PDF)

https://doi.org/10.3326/op.39

Permanent link / Trajna poveznica: https:/urn.nsk.hr/urn:nbn:hr:242:084681

Rights / Prava: Attribution-NonCommercial-NoDerivatives 4.0 International/ImenovanjeNekomercijalno-Bez prerada 4.0 međunarodna

Download date / Datum preuzimanja: 2023-04-26

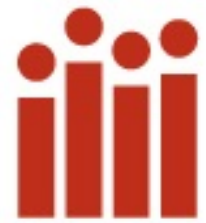

Institute of Public Finance Repository

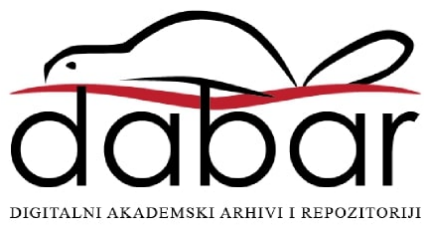


Institut za

javne financije

Smičiklasova 21 | Zagreb

www.ijf.hr | ured@ijf.hr

T: 01/4886-444 | F: 01/4819-365

\section{ODABRANI}

PRIJEVODI

\section{BR. 39}

\section{6.}

ISSN $1847-7445$

\section{POREZNI KLIN U HRVATSKOJ, ITALIJI, IRSKOJ, NIZOZEMSKOJ I ŠPANJOLSKOJ}

MAG. MATH MAJA CUNDiĆ ${ }^{*}$

PRETHODNO PRIOPĆENJE**

JEL: H21, H24, J38

DOI: $10.3326 /$ op.39

\section{SAŽETAK}

Porezni sustav svake zemlje je jedinstven te ga čine brojne komponente koje su odraz porezne, ali i cjelokupne gospodarske politike zemlje. Cilj rada je analizirati i usporediti porezno opterećenje dohotka od rada u Hrvatskoj, Italiji, Španjolskoj, Irskoj i Nizozemskoj. Pritom se promatraju različiti tipovi obitelji i različite razine bruto plaće. Rezultati pokazuju da među promatranim zemljama Italija ima najveći porezni klin. Za većinu promatranih obitelji i samaca Hrvatska se prema poreznom opterećenju nalazi u sredini odabranih zemalja. Irska se ističe s prilično niskim iznosima poreznog klina.

Ključne riječi: oporezivanje dohotka od rada, progresivnost, porezni klin, neto prosječna porezna stopa, Hrvatska, Italija, Španjolska, Irska, Nizozemska citirati: Cundić, M., 2016. Tax wedge in Croatia, Italy, Ireland, the Netherlands and Spain. Financial Theory and Practice, 40 (2), str. 201-230. Dostupno na: <http://www.fintp.hr/upload/files/ftp/ 2016/2/cundic.pdf>.
Svi Odabrani prijevodi dostupni su na: http://www.ijf.hr/hr/publikacije/casopi si/12/odabrani-prijevodi/111/

\footnotetext{
* Autorica zahvaljuje anonimnim recenzentima na njihovim korisnim komentarima i prijedlozima. Ovaj članak je dio posebnog izdanja časopisa Financial Theory and Practice, posvećenom usporedbi poreznog klina na dohodak od rada u Hrvatskoj i drugim zemljama EU-a. Članci u tom izdanju su nastali na temelju studentskog istraživačkog projekta poduzetog 2015. Predgovor posebnom izdanju (Urban, 2016.) opisuje motivaciju istraživačkog projekta, objašnjava najvažnija metodološka pitanja te pruža pregled literature o mjerenju poreznog klina u Hrvatskoj.

Stavovi izneseni u ovom radu su isključivo stavovi autorice i ne odražavaju stavove institucija u kojoj je zaposlena.

** Primljeno: 10. veljače 2016.

Prihvaćeno: 6. travnja 2016.
}

\section{Maja CUNDIĆ}

Hrvatska agencija na nadzor financijskih usluga, Miramarska 24b, 10000 Zagreb e-mail: maja.cundic@hanfa.hr 


\section{UVOD}

Svaku današnju uređenu zemlju, između ostalog, opisuje njezin porezni sustav. Njegova efikasnost može bitno utjecati na gospodarstvo, ekonomsku razvijenost, imovinsku strukturu stanovništva, broj zaposlenih i nezaposlenih, a i na samo zadovoljstvo građana. Ne postoji neki općeprihvaćeni sustav oporezivanja, primjerice, među zemljama Europske unije (EU), već se u svakoj zemlji oblikuje na jedinstven način.

Cilj ovoga rada je analizirati porezno opterećenje dohotka od rada u Hrvatskoj i odabranim zemljama EU-a - Italiji, Španjolskoj, Irskoj i Nizozemskoj, te ga usporediti na temelju određenih pokazatelja poreznog opterećenja u 2013. Ova usporedna analiza zasnovana je na Taxing Wages metodologiji, a dio je istraživanja opisanog u Urban (2016.).

Glavno pitanje koje se postavlja jest kako porezno opterećenje ovisi o iznosu bruto plaće, o tipu obitelji i broju djece. Nadalje, želi se utvrditi koje su sličnosti i razlike u sustavima poreza na dohodak te doprinosima za socijalno osiguranje u odabranim zemljama EU-a.

Dobiveni rezultati pokazuju da porezni klin uistinu ovisi o razini dohotka od rada, da se smanjuje ako porezni obveznik ima više djece i da se razlikuje među zemljama za isti tip obitelji. Nadalje, promatrajući nekoliko razina bruto plaće, pokazuje se da su iznosi doprinosa različiti u odabranim zemljama te da se teret doprinosa raspodjeljuje između poslodavca i posloprimca na razne načine o kojima u konačnici također može ovisiti veličina poreznog klina.

U drugom dijelu rada definiraju se bitni pojmovi, objašnjava se model na temelju kojeg se računaju pokazatelji te se uvode osnovne pretpostavke. U trećem dijelu slijedi prikaz oporezivanja dohotka od rada u svakoj od zemalja zasebno, gdje je prvo riječ o općenitoj strukturi oporezivanja u pojedinoj zemlji, nakon čega su prikazani izračuni za 2013. godinu. U četvrtom se dijelu dobiveni rezultati međusobno uspoređuju, a peti dio sadrži zaključak.

\section{METOdologiJA: MOdEL I POKAZATELJI}

U svrhu računanja pokazatelja poreznog opterećenja te ostalih varijabli potrebnih za njihov izračun, u ovom radu koristi se metodologija u skladu s OECD-ovom publikacijom Taxing Wages (OECD, 2014.). Premda se porezni sustavi zemalja razlikuju, moguće je povući paralelu između određenih termina pa se u nastavku opisuju pretpostavke i model pomoću kojih će biti moguće usporediti već spomenute varijable u različitim zemljama.

Promatrani tipovi obitelji su samac, par bez djece, par s dvoje djece te samohrani roditelj s dvoje djece. Pritom pojam "samac" predstavlja pojedinca, odnosno osobu koja živi bez bračnog ili izvanbračnog partnera, neovisno o spolu, dok se parom smatra bračni par. Ako se promatra par ili samac s dvoje djece, glavna je pretpostavka da su djeca u dobi od šest do uključivo jedanaest godina te da nemaju nikakvih vlastitih prihoda. U skladu s OECD-om (2014.), definira se osam hipotetskih jedinica čija obilježja prikazuje Tablica 1. 
TABLICA 1.

Obilježja promatranih hipotetskih jedinica

\begin{tabular}{lcccc}
$\begin{array}{l}\text { Oznaka u } \\
\text { ovom radu }\end{array}$ & Odrasli članovi & Broj djece & $\begin{array}{c}\text { Supružnik I } \\
\text { (\% AGW-a) }\end{array}$ & $\begin{array}{c}\text { Supružnik II } \\
\text { (\% AGW-a) }\end{array}$ \\
\hline 1A-67-NC & samac & 0 & $2 / 3 \times 100$ & - \\
\hline $1 \mathrm{~A}-100-\mathrm{NC}$ & samac & 0 & 100 & - \\
\hline $1 \mathrm{~A}-167-\mathrm{NC}$ & samac & 0 & $5 / 3 \times 100$ & - \\
\hline 1A-67-2C & samac & 2 & $2 / 3 \times 100$ & ne radi \\
\hline $2 \mathrm{~A}-100 / 0-2 \mathrm{C}$ & par & 2 & 100 & $1 / 3 \times 100$ \\
\hline $2 \mathrm{~A}-100 / 33-2 \mathrm{C}$ & par & 2 & 100 & $2 / 3 \times 100$ \\
\hline $2 \mathrm{~A}-100 / 67-2 \mathrm{C}$ & par & 2 & 100 & $1 / 3 \times 100$ \\
\hline $2 \mathrm{~A}-100 / 33-\mathrm{NC}$ & par & 0 & 100 & \\
\hline
\end{tabular}

Napomena: kratice su zasnovane na engleskom jeziku. Značenje pojedinih simbola je sljedeće: AGW - average gross wage (prosječna bruto plaća); $A$ - adult (odrasla osoba); $N C$ - no children (bez djece); $2 C$ - 2 children (dvoje djece).

Izvor: OECD (2014.).

Sukladno s OECD-om (2014.), pretpostavlja se da je jedini izvor dohotka hipotetskih jedinica bruto plaća odraslih članova, koji su zaposleni na puno radno vrijeme. Također, analiziraju se godišnje bruto plaće na različitim razinama prosječne godišnje bruto plaće (AGW; eng. average gross wage), . Model točnije koristi 1/3 AGW-a, što odgovara oznaci 33\% AGW-a, zatim 2/3 za 67\% AGW-a te naposljetku $5 / 3$ za 167\% AGW-a. Takve oznake koriste se i u ovom radu (vidjeti Urban, 2016.). Tablica 2 prikazuje iznose AGW-a koji se koriste u istraživanju, a odnose se na 2013.

\section{TABLICA 2.}

Godišnje prosječne bruto plaće u odabranim zemljama, 2013.

\begin{tabular}{lccc} 
& AGW u nacionalnoj valuti & Tečaj & AGW (u eurima) \\
\hline Hrvatska & HRK 93.180 & HRK/EUR $=7,5735$ & 12.303 \\
\hline Italija & EUR 29.704 & 1 & 29.704 \\
\hline Španjolska & EUR 26.027 & 1 & 26.027 \\
\hline Irska & EUR 32.381 & 1 & 32.381 \\
\hline Nizozemska & EUR 48.109 & 1 & 48.109
\end{tabular}

Izvor: (1) AGW - za Hrvatsku: autoričin izračun prema DZS (2016.) i Urban (2016.); za ostale zemlje: OECD (2014.); (2) tečaj za Hrvatsku: HNB (2016.).

Doprinosi za socijalno osiguranje su, za razliku od poreza, namjenski javni prihod, a odnose se, primjerice, na zdravstveno i mirovinsko osiguranje te su ih dužni plaćati poslodavci i posloprimci na način na koji je određeno u pojedinoj zemlji. Pojam trošak rada označava zbroj bruto plaće i doprinosa poslodavca, dok neto plaća odgovara iznosu bruto plaće umanjenom za doprinose posloprimca i poreze na dohodak.

Termin dohodak koristi se kao naziv za iznos koji se oporezuje te se on kod nekih zemalja umanjuje za osobni odbitak kako bi se dobila porezna osnovica. Osobni odbitak može sadržavati osnovni odbitak, odbitak za djecu, uzdržavane članove obitelji i drugo. Druga vrsta olakšice je umanjenje poreza koja, za razliku od osobnog odbitka, djeluje nakon primjene poreznih stopa, a također se može sastojati od različitih komponenti: osnovno umanjenje, umanjenje za djecu i drugo. Sve 
promatrane zemlje osim Hrvatske koriste umanjenje poreza. Osim navedenog, u analizi se u obzir uzimaju i novčane naknade za obitelj, koje isplaćuju sve razine državne vlasti.

Neto prosječna porezna stopa predstavlja udio zbroja poreza na dohodak i doprinosa posloprimca, umanjenog za novčane naknade za obitelj, u bruto plaći. Neto prosječni porezni klin (ili skraćeno: porezni klin) jest udio zbroja svih poreza i doprinosa, umanjenog za novčane naknade za obitelj, u trošku rada (Urban, 2016.).

Izračun poreznog klina u radu odnosi se isključivo na dohodak od nesamostalnog rada, i to na plaće. Oporezivanje drugih vrsta dohodaka od rada, kao što su dohodak od samostalne djelatnosti i drugi dohodak, nije uzeto u obzir u ovom radu.

Oporezivanje u svakoj od promatranih zemalja je progresivno, što znači da se neto prosječna porezna stopa pojedine osobe povećava s povećanjem dohotka (IJF, 2016.). Uz porez na dohodak, mogu postojati i druga davanja državi, kao što su lokalni, općinski, gradski porezi i slično.

Važno je naglasiti da se pod doprinose posloprimca i poslodavca uzimaju u obzir samo doprinosi koji se plaćaju općoj državi, dok su doprinosi uplaćeni u fondove izvan opće države isključeni iz analize. Primjerice, u Hrvatskoj postoje doprinosi posloprimca u dva stupa mirovinskog osiguranja - u prvi i drugi stup. Doprinosi posloprimca u prvi stup su prihodi opće države, a doprinosi za drugi stup su prihodi obveznih privatnih fondova. Stoga će prvi ući u izračun pokazatelja poreznog opterećenja, a drugi neće. O ovoj temi opširnije vidjeti u Urban (2016.), Blažić i Trošelj (2012.), OECD (2014., 2015.).

\section{OPOREZIVANJE DOHOTKA OD RADA U ODABRANIM ZEMLJAMA}

\subsection{HRVATSKA}

\subsubsection{OSNOVNI ELEMENTI OPOREZIVANJA RADA U HRVATSKOJ}

Doprinosi za socijalno osiguranje sastoje se od doprinosa posloprimca, za koje su obveznici radnici i od doprinosa poslodavca, za koje je obveznik poslodavac. Doprinosi posloprimca ukupno iznose $20 \%$ bruto plaće i odnose se na doprinose za mirovinsko osiguranje. Sastoje se od doprinosa u prvi (15\%) i drugi (5\%) stup mirovinskog osiguranja. Doprinose poslodavca koje je poslodavac dužan obračunavati i plaćati čine doprinos za zdravstveno osiguranje od 13\%, doprinos za slučaj ozljede na radu od 0,5\% te doprinos za zapošljavanje od 1,7\%, dakle ukupno 15,2\% iznosa bruto plaće u 2013. (Zakon o doprinosima, 2012.).

Obveznikom poreza na dohodak smatra se svaka osoba koja ostvaruje dohodak. Dohodak prema svom izvoru može biti dohodak od nesamostalnog rada, dohodak od samostalne djelatnosti, imovine i imovinskih prava, kapitala, osiguranja i drugih primitaka (Zakon o porezu na dohodak, 2015.). Kao što je već rečeno, pretpostavka modela nalaže da promatramo dohodak od nesamostalnog rada (samo plaće) kao jedini izvor.

Osobni odbitak je iznos koji umanjuje poreznu osnovicu obveznika (Tablica 3). ${ }^{1}$ Osim dolje navedenih odbitaka, postoje i određeni odbitci za invaliditet, no za potrebe ovog istraživanja oni nisu uzeti u obzir.

\footnotetext{
${ }^{1}$ U ovom radu ne razmatraju se područja posebne državne skrbi i brdsko-planinska područja na kojima vrijede drugačije visine osnovnog osobnog odbitka.
} 
TABLICA 3.

Osobni odbitak poreznog obveznika (Hrvatska, 2013.)

\begin{tabular}{lcc} 
Osobni odbitak & Faktor & Godišnja svota (u eurima) \\
\hline Osnovni osobni odbitak & 1,0 & 3.486 \\
\hline Odrasli uzdržavani član & 0,5 & 1.744 \\
\hline Prvo dijete & 0,5 & 1.744 \\
\hline Drugo dijete & 0,7 & 2.441 \\
\hline Treće dijete & 1,0 & 3.487 \\
\hline Četvrto dijete & 1,4 & 4.882 \\
\hline Peto dijete & 1,9 & 6.626
\end{tabular}

Izvor: Zakon o porezu na dohodak (2012.).

Ukupni osobni odbitak dobije se zbrajanjem svih odbitaka koje porezni obveznik ostvaruje. Oduzimanjem osobnog odbitka od dohotka dobije se porezna osnovica koja se zatim oporezuje progresivno.

\section{TABLICA 4.}

Godišnji porezni razredi i porezne stope (Hrvatska, 2013.)

Godišnja porezna osnovica (u eurima)

Stopa (\%)

\begin{tabular}{ll}
\hline Do 3.487 & 12 \\
\hline $3.487-13.950$ & 25 \\
\hline Iznad 13.950 & 40
\end{tabular}

Izvor: Zakon o porezu na dohodak (2012.).

U Hrvatskoj je u primjeni metoda direktne lomljene progresije, što znači da je konačni iznos poreza na dohodak zbroj dobivenih poreza po pojedinom poreznom razredu, a koji su rezultat primjene pripadne porezne stope na pojedini porezni razred (Tablica 4). Dakle, prvih 3.487 eura osnovice množi se s 0,12, sljedećih 10.463 eura osnovice (odnosno iznos osnovice između 3.487 i 13.950 eura) s 0,25 , a preostali iznos porezne osnovice množi se s 0,4 . Zatim se dobiveni umnošci zbroje, čime se dobiva iznos poreza na dohodak.

Osim poreza na dohodak, postoji i prirez, porez koji lokalne jedinice (gradovi i općine) mogu, ali ne moraju uvesti. Računa se kao određeni postotak poreza na dohodak (ovisno o gradu ili općini)(Zakon o porezu na dohodak, 2012.). U ovom radu korištena je stopa prireza od $12 \%$.

Samohrani roditelji i parovi s djecom imaju pravo primiti novčane naknade za obitelj, odnosno doplatak za djecu ako zadovoljavaju određene uvjete. Prema HZMO-u (2016.), pravo na doplatak za djecu stječe korisnik ako mu ukupni dohodak, ostvaren u prethodnoj kalendarskoj godini po članu kućanstva mjesečno ne prelazi 50\% proračunske osnovice. Mjesečna proračunska osnovica određuje se svake godine Zakonom o izvršavanju Državnog proračuna RH, a 2013. je iznosila 439 eura. ${ }^{2}$ Svota doplatka za djecu određuje se ovisno o visini ukupnog neto dohotka po članu kućanstva mjesečno. ${ }^{3}$ Ako ukupni neto dohodak po članu kućanstva mjesečno ne prelazi 16,33\% proračunske osnovice, doplatak za djecu dodjeljuje se u visini od $9 \%$ od proračunske osnovice po djetetu.

2 Prema Zakonu o izvršavanju Državnog proračuna Republike Hrvatske za 2013. godinu.

3 U slučaju osoba koje ostvaruju dohodak od rada (posloprimci), neto dohodak je bruto plaća umanjena za doprinose posloprimca te za iznos poreza i prireza. 
Nadalje, ako ukupni neto dohodak po članu kućanstva mjesečno iznosi između 16,34 i 33,66\% proračunske osnovice, doplatak za djecu iznosi 7,5\% proračunske osnovice po djetetu. Ako ukupni neto dohodak po članu kućanstva mjesečno iznosi između 33,67 i 50\% proračunske osnovice, doplatak za djecu dodjeljuje se u visini od $6 \%$ proračunske osnovice po djetetu. Osim toga, doplatak za dijete s jednim roditeljem uvećava se za $15 \%$ već pripadajućeg doplatka.

\subsubsection{POREZNI KLIN U HRVATSKOJ}

Kako bi se izračunali pokazatelji poreznog opterećenje za Hrvatskoj u 2013., izrađen je mikrosimulacijski model za hipotetske jedinice (Tablica 1), koji na temelju zadanih obilježja izračunava doprinose za socijalno osiguranje, porez na dohodak, prirez i novčane naknade za obitelj. Zatim se izračunava neto prosječna porezna stopa te neto prosječni porezni klin.

Kako je već navedeno, prema DZS-u (2014.) prosječna mjesečna bruto plaća u 2013. iznosi 1.025 eura, što je na godišnjoj razini 12.303 eura. Bitno je napomenuti da iznos od jedne trećine AGW-a, koji se pojavljuje kod hipotetskih jedinica 2A-100/33-2C i 2A-100/33-NC, nije u skladu sa Zakonom o minimalnoj plaći iz 2013. Naime, iznos od 1/3 AWG-a je 342 eura, što je niže od minimalne bruto plaće, koja je u 2013. iznosila 394 eura. Ipak, zbog konzistentnosti s OECD-om (2014.) svejedno se koristi taj iznos prilikom izračuna pokazatelja za spomenute hipotetske jedinice.

Prilikom izračuna svote doplatka za djecu pretpostavlja se da je u prošloj kalendarskoj godini neto dohodak obitelji iznosio koliko i u 2013. Tako pravo na doplatak ostvaruje samac s dvoje djece, koji prima bruto plaću u iznosu od 67\% AGW-a (1A-67-2C), u iznosu od 727 eura godišnje (632 eura osnovnog iznosa i dodatnih 95 eura s obzirom da je samohrani roditelj) i par s dvoje djece gdje prvi član prima 100\% AGW-a, a drugi nema prihode (2A-100/0-2C), u iznosu od 632 eura.

Tablice A1 i A2 u dodatku sadrže detaljan izračun pokazatelja poreznog opterećenja u Hrvatskoj 2013. Grafikon 1 prikazuje neto prosječni porezni klin i neto prosječnu poreznu stopu za svih osam hipotetskih jedinica.

Jasno se uočava progresivnost u oporezivanju dohotka od rada. Tako je neto prosječni porezni klin samca sa $100 \%$ AGW-a (1A-100-NC) veći nego kod samca sa 67\% AGW-a (1A-67-NC), ali manji nego porezni klin samca čija je godišnja bruto plaća na razini 167\% AGW-a (1A-167-NC). Također, promatrajući samohranog roditelja s dvoje djece (1A-67-2C), može se uočiti smanjenje poreznog klina u odnosu na samca s jednakom bruto plaćom dohotkom, ali bez djece (1A-67-NC).

Znatno manji porez na dohodak i prirez vidljivi su u analizi poreznog klina parova s i bez djece (tablica A2). Prilikom izračuna ukupnih davanja, bračni partneri gledaju se odvojeno, svatko plaća određeni porez na dohodak, ovisno o visini svoje bruto plaće, a odbitak za djecu u ovom slučaju dan je osobi s većom godišnjom bruto plaćom, dakle onome partneru koji ostvaruje 100\% AGW-a. Konačni izdaci kućanstva iz bruto plaće dobiju se zbrajanjem izdataka svakog od partnera.

Porezni klin samca s dvoje djece i bruto plaćom na razini od 67\% AGW-a (1A-67-2C) iznosi 18,5\% (Grafikon 1). To je bitno manje od poreznog klina samca bez djece sa 67\% AGW-a (1A-67-NC). Osjetno manji porezni klin imaju parovi s djecom. Porezni klin para s dvoje djece i bruto plaćama od 100 i 33\% AGW-a (2A-100/33-2C) niži je za 5,1 postotnih bodova poreznog klina para bez djece također s bruto plaćama od 100 i 33\% AGW-a (2A-100/33-NC). Usporedi li se klin samca bez djece sa $100 \%$ AGW-a (1A-100-NC) s klinom para s djecom u kojem samo jedan od supružnika ima 
prihode, također u iznosu od 100\% AGW-a (2A-100/0-2C), može se uočiti da uzdržavanje supružnika i dvoje djece znači smanjenje klina za 13 postotnih bodova. Za to smanjenje zaslužno je uvećanje osobnog odbitka te pravo na doplatak za djecu.

\section{GRAFIKON 1.}

Neto prosječni porezni klin i neto prosječna porezna stopa za hipotetske jedinice (Hrvatska, 2013.), u \%

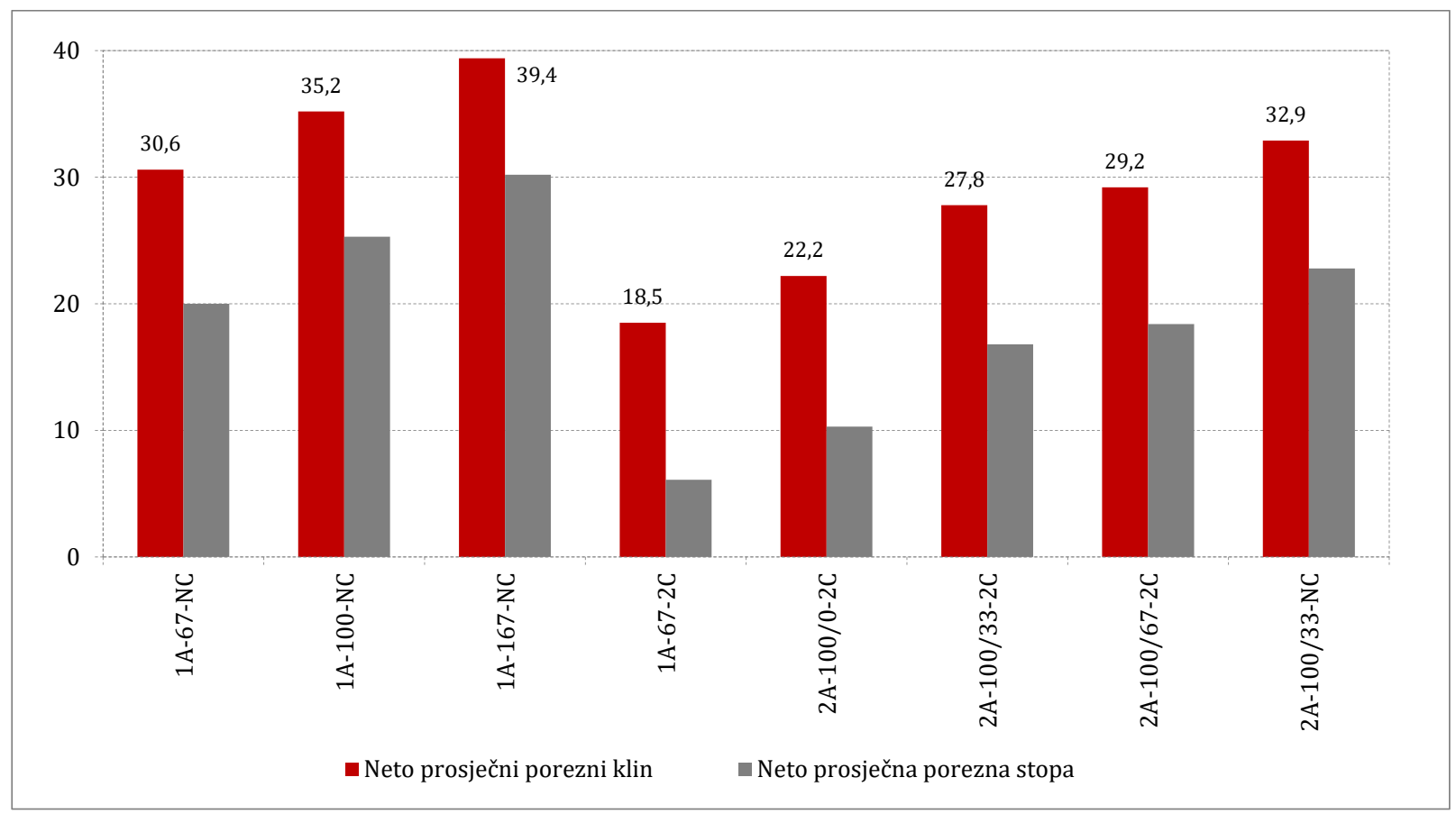

Izvor: autoričini izračuni.

\subsection{ITALIJA}

\subsubsection{OSNOVNI ELEMENTI OPOREZIVANJA RADA U ITALIJI}

Prema OECD-u (2014.), doprinosi posloprimaca iznose 9,49\% bruto plaće ako ona ne premašuje 45.530 eura. Za bruto plaću između 45.530 i 99.034 eura stopa iznosi 10,49\%, a za bruto plaću iznad 99.034 eura doprinosi su fiksni te iznose 10.072 eura. Doprinosi poslodavca iznose 32,08\% bruto plaće ako je ona niža od 99.034 eura godišnje. Za sve veće iznose poslodavac izdvaja 31.770 eura godišnje.

Olakšice u sustavu poreza na dohodak postoje u obliku umanjenja poreza, dakle djeluju nakon primjene poreznih stopa po razredima (tablice 5 i 6 ).

\section{TABLICA 5.}

Godišnje umanjenje poreza, u eurima (Italija, 2013.)

Oporezivi dohodak

Osnovno umanjenje poreza

\begin{tabular}{lc}
\hline Do 8.000 & 1.840 \\
\hline $8.001-15.000$ & $\max +502 *(15.000$-oporezivi dohodak $) / 7.000$ \\
\hline $15.001-55.000$ & $\max ^{*}(55.000$-oporezivi dohodak $) / 40.000$ \\
\hline Iznad 55.000 & 0 \\
\hline Izvor: OECD $(2014)$. &
\end{tabular}

Izvor: OECD (2014.). 


\section{TABLICA 6.}

Godišnje umanjenje poreza, u eurima (Italija, 2013.), nastavak

\section{Razina oporezivog dohotka}

\section{Najviši iznos}

\begin{tabular}{ll}
\hline $8.001-15.000$ & 1.338 \\
\hline $15.001-23.000$ & 1.338 \\
\hline $23.001-24.000$ & 1.348 \\
\hline $24.001-25.000$ & 1.358 \\
\hline $25.001-26.000$ & 1.368 \\
\hline $26.001-27.000$ & 1.378 \\
\hline $27.001-28.000$ & 1.363 \\
\hline $28.001-55.000$ & 1.338 \\
\hline
\end{tabular}

Izvor: OECD (2014.).

Umanjenje poreza za djecu dobije se kao funkcija oporezivog dohotka na sljedeći način:

— umanjenje za obitelj s jednim djetetom:

$$
\text { CTC1 }=950 *(95.000-\text { oporezivi dohodak }) / 95.000
$$

— za obitelj s više djece, iznos od 95.000 iz jednadžbe (1) povećava se za 15.000 za svako sljedeće dijete te se svi dobiveni iznosi zbrajaju

— obitelj s više od troje djece dobiva dodatnih 200 eura umanjenja po djetetu.

U tablici 7 prikazani su iznosi umanjenja poreza za uzdržavanog supruga za različite oporezive dohotke.

TABLICA 7.

Godišnje umanjenje poreza za uzdržavanog supružnika (Italija, 2013.), u eurima

\section{Razina oporezivog dohotka}

Do 15.000

$15.001-29.000$

$29.001-29.200$

$29.201-34.700$

$34.701-35.000$

$35.001-35.100$

$35.101-35.200$

$35.201-40.000$

$40.001-80.000$

Iznad 80.000

Izvor: OECD (2014.).

Tablica 8 prikazuje porezne razrede kojih u Italiji ima pet. Primjerice, dio porezne osnovice veći od 28.000, a manji od 55.000 eura godišnje oporezuje se stopom od 38\%.

\section{Iznos umanjenja}

800-110*oporezivi dohodak/15.000

690

700

710

720

710

700

690

$690 *(80.000$-oporezivi dohodak)/40.000

0 
TABLICA 8.

Porezni razredi i stope (Italija, 2013.)

\begin{tabular}{lc} 
Porezni razred (u eurima) & Stopa (\%) \\
\hline Do 15.000 & 23 \\
\hline $15.000-28.000$ & 27 \\
\hline $28.000-55.000$ & 38 \\
\hline $55.000-75.000$ & 41 \\
\hline Iznad 75.000 & 43 \\
\hline
\end{tabular}

Izvor: OECD (2014.).

Osim poreza na dohodak, postoje i regionalni i lokalni porezi, a izvedeni su kao određeni postotak oporezivog dohotka, ovisno o regiji.

\subsubsection{POREZNI KLIN U ITALIJI}

U modelu se koriste stope regionalnog i lokalnog poreza od 1,73\% i 0,9\%, što odgovara stopama glavnoga grada Rima. Dakle, ukupni porezi su zbroj poreza na dohodak nakon umanjenja poreza te ukupnog lokalnog poreza od 2,63\%. Porez na dohodak u kućanstvu računa se posebno za svakog od bračnih partnera.

Tablice A3 i A4 u dodatku sadrže detaljan izračun pokazatelja poreznog opterećenja u Italiji 2013. Grafikon 2 prikazuje neto prosječni porezni klin i neto prosječnu poreznu stopu za svih osam hipotetskih jedinica.

\section{GRAFIKON 2.}

Neto prosječni porezni klin i neto prosječna porezna stopa za hipotetske jedinice (Italija, 2013.), u \%

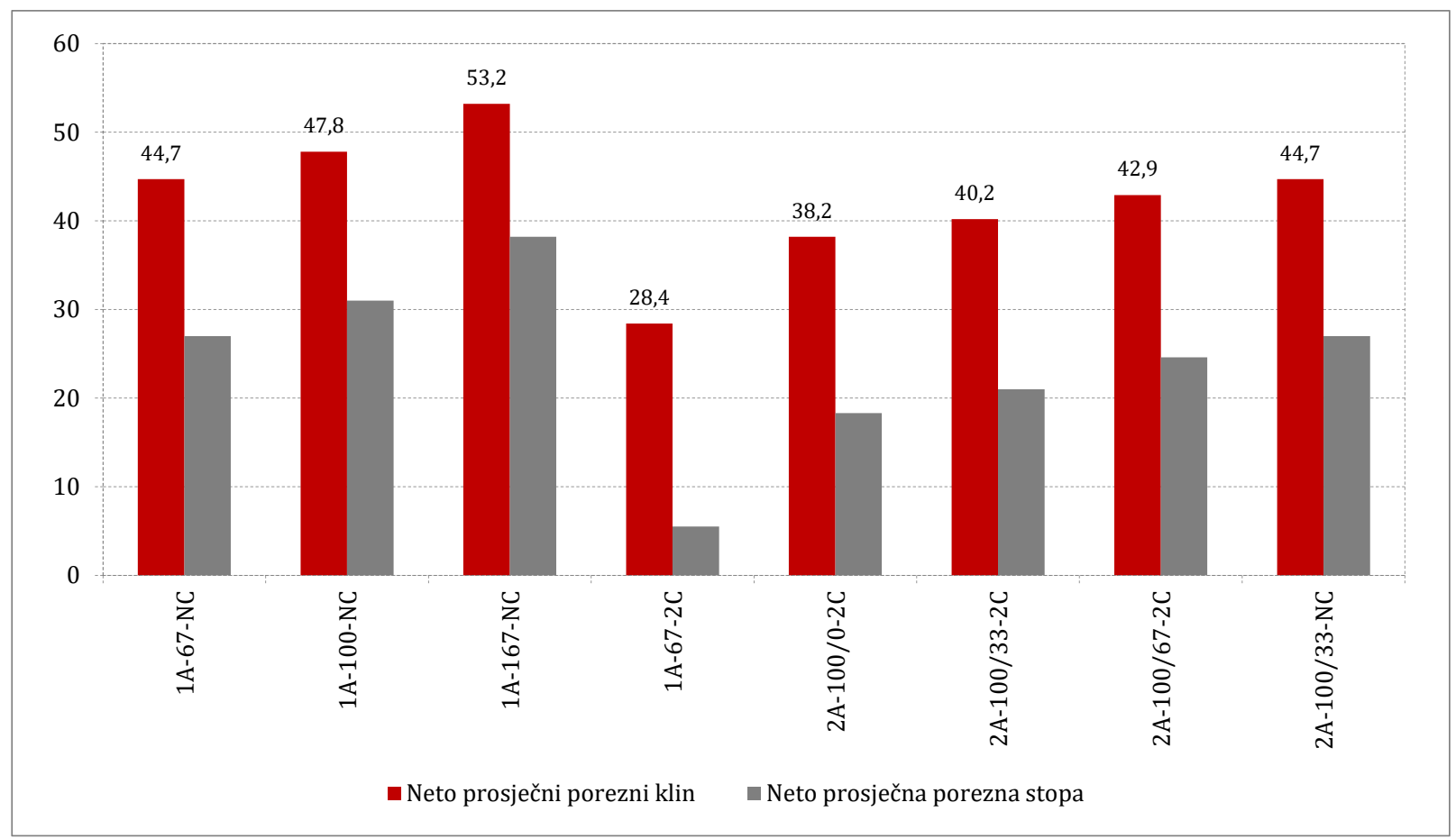

Izvor: autoričini izračuni na temelju OECD (2014.). 
Samci s bruto plaćom na razini od 167\% AGW-a (1A-167-NC) snose porezno opterećenje od čak $53,2 \%$ (tablica A3). Međutim, za samohranog roditelja (1A-67-2C) porezni klin je bitno manji i iznosi $28,4 \%$. Naime, osim umanjenja poreza za dvoje djece ta hipotetska jedinica prima i novčane naknade za obitelj.

Usporedbom hipotetskih jedinica s djecom i bez djece može se uočiti utjecaj poreznih olakšica i novčanih naknada za obitelj na porezni klin (Grafikon 2). Porezni klin raste s bruto plaćom, što svjedoči o progresivnosti sustava (usporediti jedinice 1A-67-NC, 1A-100-NC i 1A-167-NC, odnosno 2A-100/0-2C, 2A-100/33-2C i 2A-100/67-2C).

\section{3. ŠPANJOLSKA}

\subsubsection{OSNOVNI ELEMENTI OPOREZIVANJA RADA U ŠPANJOLSKOJ}

Prema OECD-u (2014.) i Adiego et al. (2014.), doprinosi posloprimaca u Španjolskoj odnose se na starosnu mirovinu i bolovanje, nezaposlenost i stručno usavršavanje, a ukupno čine 6,35\% bruto plaće, dok doprinosi poslodavca čine $29,9 \%$ te uključuju starosnu mirovinu i bolovanje, ozljede na radu, platni fond i stručno usavršavanje. Pritom je određeno da se ti udjeli računaju na iznos od 9.036 eura, kada je bruto plaća manja te na iznos od 41.108,40 eura, kada je bruto plaća veća od tog iznosa.

U Španjolskoj bračni parovi mogu odabrati način oporezivanja; moguće je oporezivati ukupan dohodak kućanstva ili se posebno oporezuje dohodak svakog od partnera. Ako se oporezuje iznos zajedničkog dohotka, obitelj može potraživati osobni odbitak u iznosu od 3.400 eura, a samohrani roditelj odbitak od 2.150 eura. Bruto plaća umanjena za doprinose posloprimaca umanjuje se još i za troškove vezane uz rad (WRE) na sljedeći način:

— Za neto dohodak manji ili jednak 9.180 eura godišnje: $W R E=4.080$ eura

— Za neto dohodak između 9.180,01 i 13.260 eura:

$$
W R E=4.080-0,35 *(\text { neto dohodak }-9.180)
$$

— Za neto dohodak iznad 13.260 eura: $W R E=2.652$ eura.

Neoporezivi dohodak iznosi 5.151 eura, bilo za pojedinog poreznog obveznika ili obitelj kojoj se oporezuje zajednički dohodak. Odbitak za prvo dijete iznosi 1.836, a za drugo 2.040 eura. Odbici za djecu dijeli se među supružnicima na jednake dijelove ako im se ukupni dohodak ne oporezuje kao zajednički.

Osim uobičajenih poreza na dohodak, postoje još i regionalni porezi.

Tablice 9 i 10 prikazuju porezne razrede i pripadne stope po kojima se računa porez na dohodak te regionalni porez. 
TABLICA 9.

Porezni razredi i stope (Španjolska, 2013.)

\begin{tabular}{lc} 
Oporezivi dohodak (u eurima) & Stopa (\%) \\
\hline Do $17.707,20$ & 12,75 \\
\hline $17.707,20-33.007,20$ & 16,00 \\
\hline $33.007,20-53.407,20$ & 21,50 \\
\hline $53.407,20-120.000,20$ & 25,50 \\
\hline $120.000,20-175.000,20$ & 27,50 \\
\hline $175.000,20-300.000,20$ & 29,50 \\
\hline Iznad $300.000,20$ & 30,50 \\
\hline
\end{tabular}

Izvor: OECD (2014.).

TABLICA 10.

Porezni razredi i stope za regionalne poreze (Španjolska, 2013.)

Oporezivi dohodak (u eurima)

\begin{tabular}{ll}
\hline Do $17.707,20$ & 12,00 \\
\hline $17.707,20-33.007,20$ & 14,00 \\
\hline $33.007,20-53.407,20$ & 18,50 \\
\hline Iznad $53.407,20$ & 21,50 \\
\hline
\end{tabular}

Izvor: OECD (2014.).

U Španjolskoj postoje obiteljske novčane naknade za uzdržavanu djecu. Tako obitelj s jednim djetetom i bruto plaćom manjom od 11.490,43 eura na godišnjoj razini, ima pravo na 291 eura potpore. Obitelj s dvoje djece i bruto plaćom nižom od 13.213,99 eura može primiti 582 eura.

\subsubsection{POREZNI KLIN U ŠPANJOLSKOJ}

U modelu sadržanom u OECD-u (2014.) svaki od parova oporezuje dohodak tako da se oni gledaju odvojeno, osim para gdje jedan od supružnika nema prihode te taj par dobiva olakšicu u iznosu od 3.400 eura godišnje. Također, samohrani roditelj dobiva olakšicu u iznosu od 2.150 eura godišnje. Nestandardne olakšice nisu uzete u obzir u ovom modelu.

Tablice A5 i A6 u dodatku sadrže detaljan izračun pokazatelja poreznog opterećenja u Španjolskoj 2013. Grafikon 3 prikazuje neto prosječni porezni klin i neto prosječnu poreznu stopu za svih osam hipotetskih jedinica.

Kao i kod prethodnih zemalja, Hrvatske i Italije, osobe s većim prihodima snose veće porezno opterećenje. Nadalje, porezni klin samohranog roditelja s dvoje djece koji prima bruto plaću u iznosu od $67 \%$ AGW-a (1A-67-2C) manji je za 6,9 postotna boda u odnosu na porezni klin samca sa $67 \%$ AGW-a (1A-67-NC).

Očito je da u Španjolskoj, za razliku od Hrvatske i Italije, potpore za djecu nisu baš izdašne, pa je razlika u klinu između para s djecom 2A-100/67-2C i para bez djece 2A-100/33-NC vrlo niska te iznosi 1,1 postotnih bodova (Grafikon 3). 
GRAFIKON 3.

Neto prosječni porezni klin i neto prosječna porezna stopa za hipotetske jedinice (Španjolska, 2013.), $u \%$

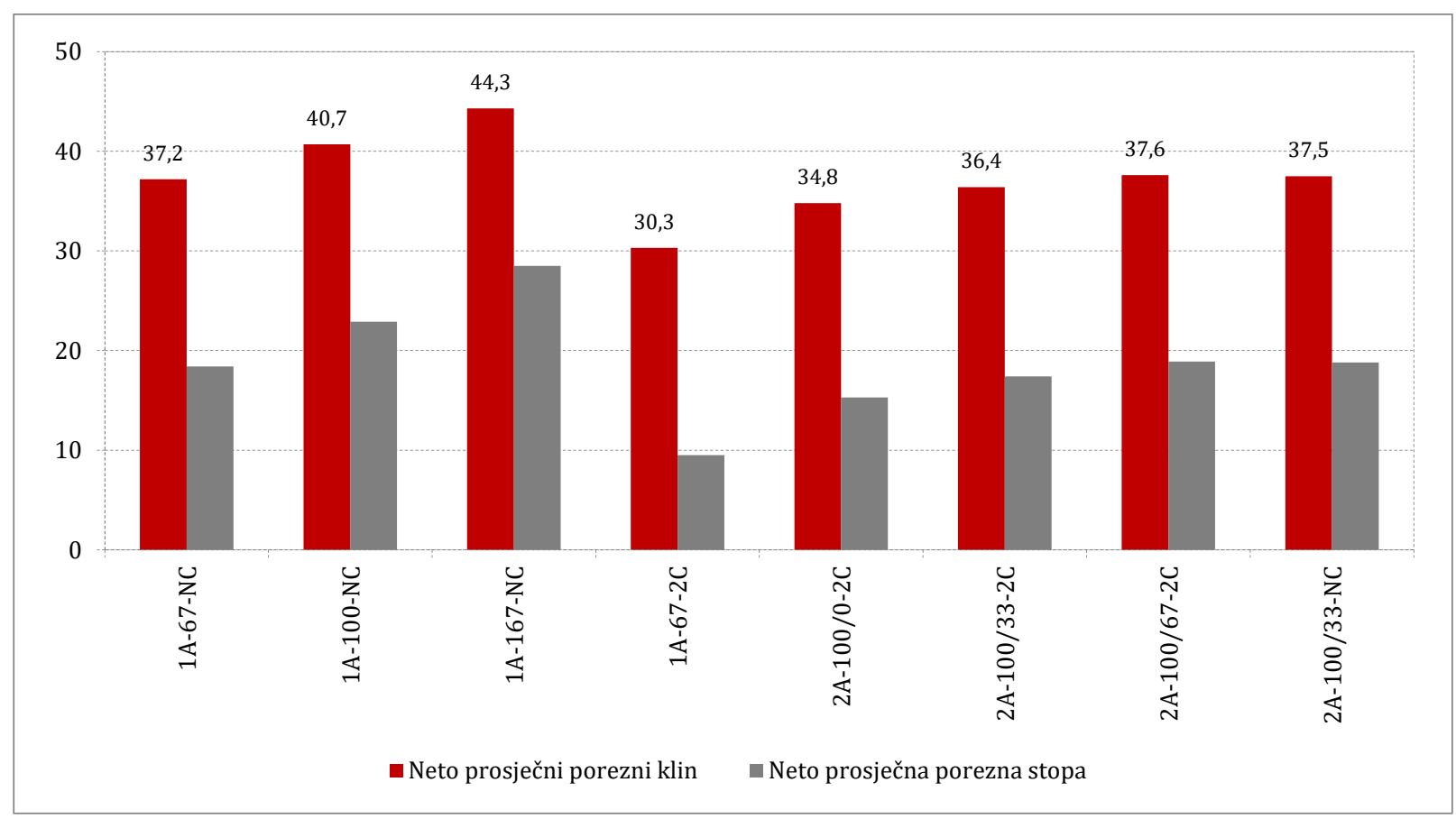

Izvor: autoričini izračuni na temelju OECD-a (2014.).

\subsection{IRSKA}

\subsubsection{OSNOVNI ELEMENTI OPOREZIVANJA RADA U IRSKOJ}

Može se reći da je porezni sustav u Irskoj nešto drugačiji od dosad promatranih sustava. Naime, cijeli iznos bruto plaće je oporeziv, a novčane naknade za obitelj mogu biti prilično visoke u određenim slučajevima. Nadalje, Irskoj je svojstven Pay Related Social Insurance (PRSI) koji su obavezni plaćati gotovo svi posloprimci i poslodavci u nacionalno Socijalno osiguranje. Shodno tome, posloprimac je dužan plaćati $4 \%$ doprinosa od bruto plaće, osim ako ona iznosi manje od 18.304 eura godišnje, a poslodavac izdvaja sveukupno 10,75\%. Spomenuti doprinosi u PRSI razvrstani su u nekoliko kategorija, ovisno o vrsti posla i visini primanja (za detalje vidjeti OECD, 2014. i O’Donoghue, 2014.). ${ }^{4}$

Osim poreza na dohodak, porezni obveznici izdvajaju i određeni postotak za Universal Social Charge (USC), koji se može poistovjetiti s doprinosom za zdravstvo. Za USC se izdvaja ovisno o visini dohotka:

- do 10.036 eura godišnje: po stopi od $2 \%$,

— između 10.036 i 16.016 eura: po stopi od $4 \%$,

— iznad 16.016 eura: po stopi od 7\%.

4 Također vidjeti: Anon (2016.). 
TABLICA 11.

Porezni razredi i stope (Irska, 2013.)

\begin{tabular}{lcccc} 
& \multicolumn{2}{c}{ Oporezivi dohodak (u eurima) } & Stopa (\%) \\
\hline Samac & $\begin{array}{c}\text { Bračni par } \\
\text { (jedan dohodak) }\end{array}$ & $\begin{array}{c}\text { Bračni par } \\
\text { (dva dohotka) }\end{array}$ & $\begin{array}{c}\text { Samohrani } \\
\text { roditelj }\end{array}$ & Do minimuma od \\
Do 32.800 & Do 41.800 & Do 36.800 & 20 \\
Ostalo & & & & 40
\end{tabular}

Izvor: OECD (2014.).

Tablica 11 prikazuje stope kojima se oporezuju različiti dijelovi dohotka. Stopom od $20 \%$ oporezuje se dohodak samca u iznosu do 32.800 eura godišnje, dohodak bračnog para koji prima samo jednu plaću u iznosu do 41.800 eura godišnje, dohodak samohranog roditelja u iznosu do 36.800 eura godišnje, a za bračni par s dva dohotka ne postoji fiksna granica. Naime, granica prvog poreznog razreda bračnog para u kojem svaki od supružnika prima plaću određuje se kao minimum od (a) iznosa od 65.600 eura; i (b) zbroja dohotka supružnika s nižim dohotkom i iznosa od 41.800 eura. Ostatak dohotka iznad ovih iznosa oporezuje se stopom od 40\%.

Osnovno umanjenje poreza za pojedinca iznosi 1.650 eura godišnje, a za bračni par dvostruko više, 3.300 eura. Nadalje, svaki radnik dobiva dodatnih 1.650 eura umanjenja poreza, a samohrani roditelj uza sve navedeno još 1.650 eura. Posebnih 180 eura pripada kućanstvu u kojem jedan od supružnika nema primanja, a brine o djeci, starijoj osobi ili nekom drugom članu obitelji (OECD, 2014.).

Univerzalna naknada za djecu iznosi 1.560 eura godišnje po djetetu. Osim toga, postoji i novčana naknada za obitelji s nižim dohotkom. Tako obitelj s dvoje djece ostvaruje naknadu čiji je iznos, $B$, jednak:

$$
B=0,6 *(31.304-\text { dohodak })
$$

\subsubsection{POREZNI KLIN U IRSKOJ}

Tablice A7 i A8 u dodatku sadrže detaljan izračun pokazatelja poreznog opterećenja u Irskoj 2013. Grafikon 4 prikazuje neto prosječni porezni klin i neto prosječnu poreznu stopu za svih osam hipotetskih jedinica.

Grafikon 4 ukazuje na niže porezno opterećenje nego što bi se moglo očekivati na temelju pregleda irskog poreznog sustava. Naime, unatoč činjenici da je porezna osnovica zapravo cjelokupni iznos bruto plaće, a porezne stope su visoke, neto prosječni porezni klin i neto prosječna porezna stopa u Irskoj znatno su niži od dosad promatranih zemalja. Uzrok tome su umanjenja poreza i prilično visoka razina novčanih naknada koji u određenim uvjetima premašuju iznos ukupnih poreza.

Osobito je zanimljivo promotriti samohranog roditelja s dvoje djece i bruto plaćom od 67\% AGWa (1A-67-2C, Grafikon 4). Naime, pripadni porezni klin je drastično manji u usporedbi s poreznim klinom osobe bez djece s bruto plaćom na razini od 67\% AGW-a (1A-67-NC). Štoviše, iznosi čak $-24,9 \%$ (negativni iznos). Visoke novčane naknade za obitelj i ukupna umanjenja poreza doveli su do ove pojave koja nije uobičajena za dosad promatrane zemlje. Neto prosječna porezna stopa je izrazito niska i negativna, a iznosi -38,3\%. Jedino što se izdvaja iz dohotka jesu izdaci za USC i manji 
iznos doprinosa posloprimca. Grafikon 4 također sugerira manje porezno opterećenje paru s dvoje djece naspram onoga kod para bez djece. Bračni par u kojem je jedan od supružnika uzdržavan, a drugi prima $100 \%$ AGW-a (2A-100/0-2C), isto tako prima višu potporu države te na taj način prilično umanjuje ukupne poreze te porezni klin iznosi svega $6,8 \%$.

\section{GRAFIKON 4.}

Neto prosječni porezni klin i neto prosječna porezna stopa za hipotetske jedinice (Irska, 2013.), u \%

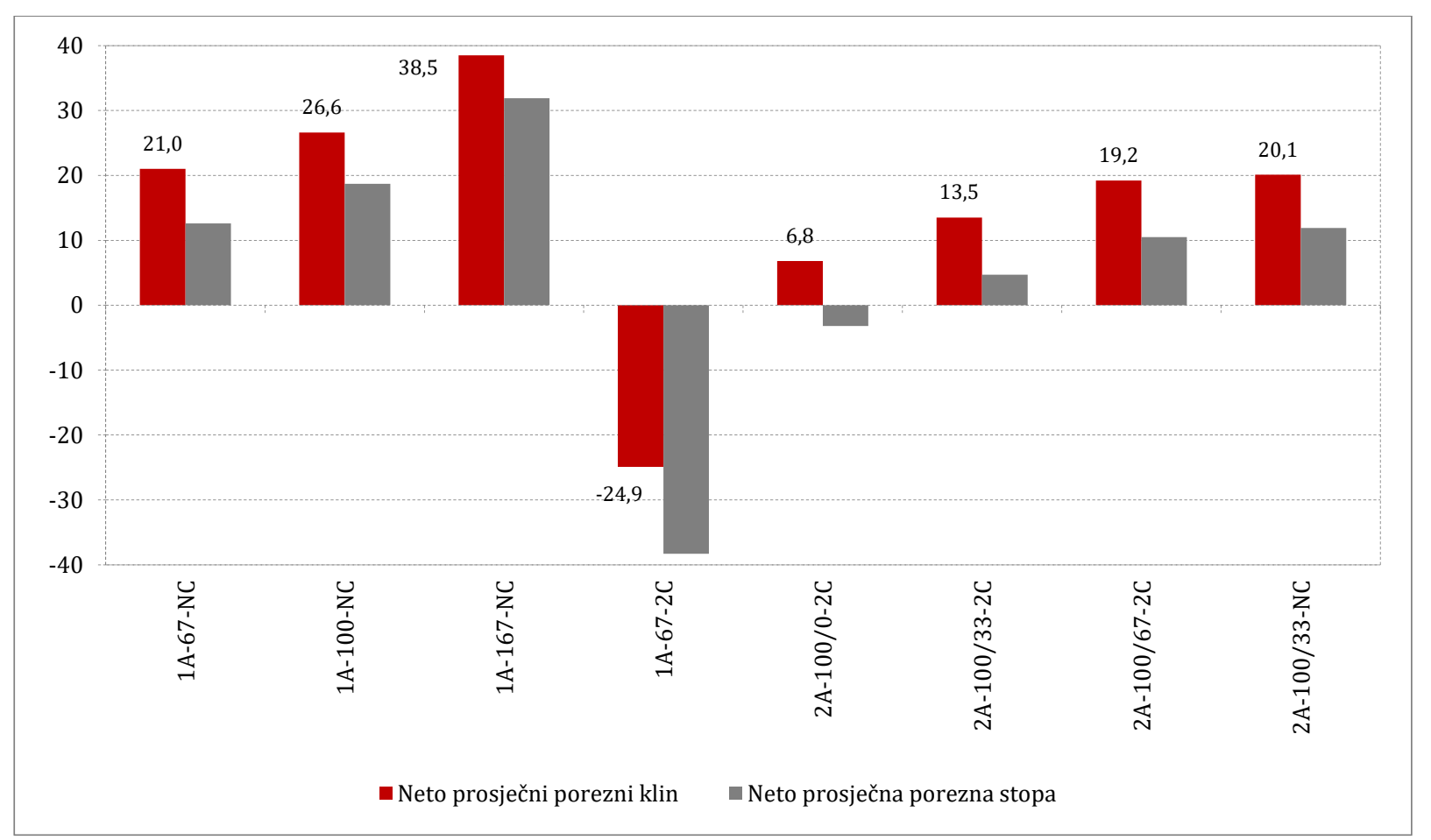

Izvor: autoričini izračuni na temelju OECD-a (2014.).

\subsection{NIZOZEMSKA}

\subsubsection{OSNOVNI ELEMENTI OPOREZIVANJA RADA U NIZOZEMSKOJ}

Porezni sustav Nizozemske izdvaja se od ostalih po nekim svojim specifičnostima. Stopa doprinosa posloprimca za opći fond nezaposlenosti iznosi $0 \%$ na godišnju bruto plaću između 17.501 i 50.853 eura. Poslodavci plaćaju premiju za nezaposlenost i za invalidnost za svoje posloprimce. Za osnovno zdravstveno osiguranje posloprimac izdvaja 1.250 eura godišnje u privatno zdravstveno osiguranje koje sam odabere, međutim taj doprinos ne uzima se u obzir u izračunu pokazatelja poreznog opterećenja jer predstavlja neporezno obvezno davanje (vidjeti Urban, 2016.). Za starosnu mirovinu posloprimac izdvaja $17,9 \%$ oporezivog dohotka ako je on manji ili jednak 33.363 eura godišnje. Inače je iznos fiksan, 5.972 eura. Na godišnju bruto plaću ispod 50.853 eura poslodavac može plaćati do $17,9 \%$ iznosa bruto plaće za doprinose za nezaposlenost, invalidnost i slično.

Umanjenje poreza odbija se djelomično od poreza na dohodak, a djelomično od doprinosa. Opće umanjenje iznosi 2.001 eura godišnje, umanjenje za rad iznosi 17,1\% oporezivog dohotka, s time da maksimalno iznosi 1.723 eura, a samohrani roditelj dobiva dodatnih 947 eura umanjenja (OECD, 2014.; de Vos i de Agostini, 2014.). 
TABLICA 12.

Porezni razredi i stope (Nizozemska, 2013.)

\begin{tabular}{lcc} 
Oporezivi dohodak (u eurima) & Porezna stopa (\%) & Stopa doprinosa (\%) \\
\hline Do 19.645 & 5,85 & 31,15 \\
\hline $19.645-33.363$ & 10,85 & 31,15 \\
\hline $33.363-55.991$ & 42 & - \\
\hline Iznad 55.991 & 52 & -
\end{tabular}

Izvor: OECD (2014.).

Novčane naknade za obitelj s dvoje djece čini zbroj dvaju dijelova: osnovnog iznosa od 1.861 eura i dodatka čiji je iznos jednak $C$, a dobiva se na sljedeći način:

$$
C=1.553-0,076 *(\text { oporezivi dohodak }-26.147)
$$

Dodatak u vrijednosti $C$ ne dobivaju obitelji s dvoje djece čiji oporezivi dohodak premašuje 46.581 eura godišnje.

\subsubsection{POREZNI KLIN U NIZOZEMSKOJ}

Tablice A9 i A10 u dodatku sadrže detaljan izračun pokazatelja poreznog opterećenja u Nizozemskoj 2013. Grafikon 5 prikazuje neto prosječni porezni klin i neto prosječnu poreznu stopu za svih osam hipotetskih jedinica.

\section{GRAFIKON 5.}

Neto prosječni porezni klin i neto prosječna porezna stopa za hipotetske jedinice (Nizozemska, 2013.), $u \%$

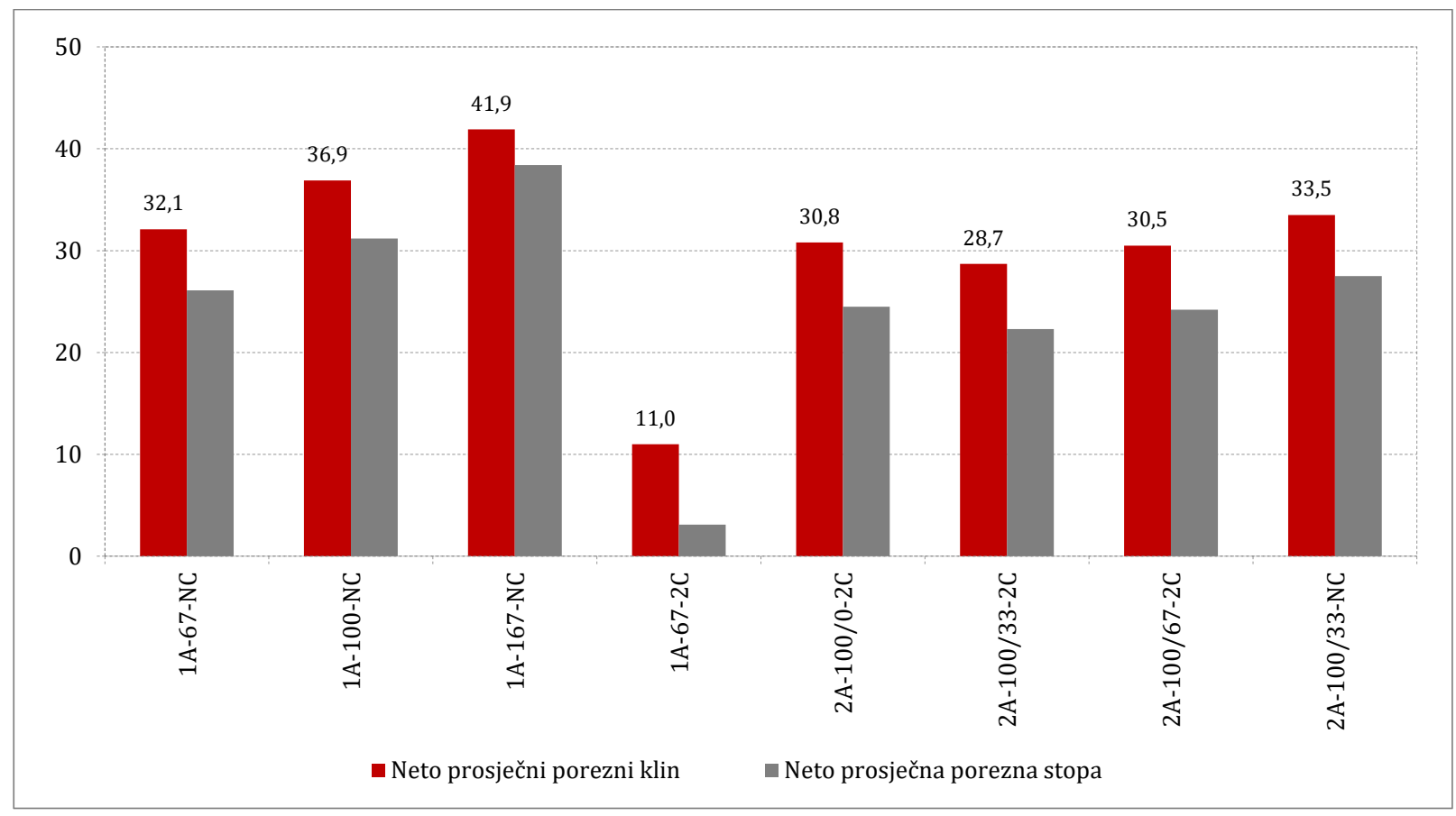

Izvor: autoričini izračuni na temelju OECD-a (2014.).

Neto prosječna porezna stopa i neto prosječni porezni klin kreću se očekivano kod samaca. Značajno manje vrijednosti mogu se uočiti kod samohranog roditelja s dvoje djece koji prima bruto 
plaću u iznosu od 67\% AGW-a (1A-67-2C), gdje je porezni klin čak 21,1 postotnih bodova manji u odnosu na samca bez djece $s$ istom bruto plaćom (1A-67-NC). Ponovno novčane naknade za obitelj igraju ključnu ulogu u toj razlici. Međutim, Grafikon 5 prikazuje pomalo neočekivano kretanje poreznog klina. Naime, par s dvoje djece i godišnjim bruto plaćama na razinama od 100 i $0 \%$ AGWa (2A-100/0-2C) snosi relativno visoko porezno opterećenje, gotovo jednako onom koje plaća par s dvoje djece i bruto plaćama u iznosu od 100 i 33\% AGW-a (2A-100/33-2C), a i njihove novčane naknade su približnih vrijednosti. Na taj način 2A-100/0-2C snosi veće porezno opterećenje od $2 \mathrm{~A}$ 100/33-2C, ali i od para s godišnjim bruto plaćama u iznosu od 100 i 67\% AGW-a (2A-100/67-2C).

\section{USPOREDBA POREZNOG OPTEREĆENJA RADA U ODABRANIM ZEMLJAMA}

Premda postoje brojne različitosti među promatranim zemljama u pogledu oporezivanja dohotka od rada, ipak imaju slične koncepte doprinosa za socijalno osiguranje, poreza na dohodak i novčanih naknada za obitelj. U svakoj od obrađenih zemalja oporezivanje je progresivno, a razlika je u broju i granicama poreznih razreda i veličini pripadnih poreznih stopi; doprinosi posloprimca uvijek uključuju doprinose za starosnu mirovinu, a doprinosi poslodavca doprinose za zdravstveno osiguranje, a razlika je u načinu na koji se doprinosi određuju i stopama koje se koriste (Čok et al., 2013.).

Rezultate izračuna neto prosječnog poreznog klina objedinjuju tablice 13 i 14 , posebno za hipotetske jedinice samce i za parove.

Rezultati prikazuju Italiju kao zemlju s najvećim udjelom poreza i doprinosa u troškovima rada. Za svaki promatrani tip obitelji i svaku razinu bruto plaće, osim u slučaju samohranog roditelja dvoje djece s godišnjom bruto plaćom na razini od 67\% AGW-a (1A-67-2C), Italija je nedvojbeno "pobjednica" u veličini poreznog klina. U slučaju hipotetske jedinice 1A-67-2C najveći porezni klin ima Španjolska u iznosu od 30,3\%, Italija je na drugom mjestu s klinom od 28,4\%, a Hrvatska na trećem s poreznim klinom od 18,5\%. Zatim slijedi Nizozemska, a Irska s negativnim poreznim klinom prilično odskače. Španjolska se u gotovo svakom slučaju nalazi na drugom mjestu, a Irska s najmanjim poreznim klinom uvijek na zadnjem. Dakle, nakon vodeće Italije i Španjolske, Hrvatska i Nizozemska se nalaze na srednjim pozicijama po veličini poreznog klina, a Irska se ističe veoma niskim, čak i negativnim klinom.

\section{TABLICA 13.}

Usporedba neto prosječnog poreznog klina za hipotetske jedinice: samce (u \%), 2013.

\begin{tabular}{lcccc} 
& $\mathbf{1 A - 6 7 - N C}$ & $\mathbf{1 A - 1 0 0 - N C}$ & $\mathbf{1 A - 1 6 7 - N C}$ & $\mathbf{1 A - 6 7 - 2 C}$ \\
\hline Hrvatska & 30,6 & 35,2 & 39,4 & 18,5 \\
\hline Italija & 44,7 & 47,8 & 53,2 & 28,4 \\
\hline Španjolska & 37,2 & 40,7 & 44,3 & 30,3 \\
\hline Irska & 21,0 & 26,6 & 38,5 & $-24,9$ \\
\hline Nizozemska & 32,1 & 36,9 & 41,9 & 11,0 \\
\hline
\end{tabular}

Izvor: autoričini izračuni na temelju OECD-a (2014.). 
TABLICA 14.

Usporedba neto prosječnog poreznog klina za hipotetske jedinice: parove (u \%), 2013.

\begin{tabular}{lcccc} 
& $\mathbf{2 A - 1 0 0 / 0 - 2 C}$ & $\mathbf{2 A - 1 0 0 / 3 3 - 2 C}$ & $\mathbf{2 A - 1 0 0 / 6 7 - 2 C}$ & 2A-100/33-BD \\
\hline Hrvatska & 22,2 & 27,8 & 29,2 & 32,9 \\
\hline Italija & 38,2 & 40,2 & 42,9 & 44,7 \\
\hline Španjolska & 34,8 & 36,4 & 37,6 & 37,5 \\
\hline Irska & 6,8 & 13,5 & 19,2 & 20,1 \\
\hline Nizozemska & 30,8 & 28,7 & 30,5 & 33,5 \\
\hline
\end{tabular}

Izvor: autoričini izračuni na temelju OECD-a (2014.).

Grafikoni 6 do 13 prikazuju usporednu analizu neto prosječnog poreznog klina za sve odabrane zemlje, zasebno za svaku hipotetsku jedinicu. Pri tome je porezni klin dekomponiran na tri dijela, koji predstavljaju udjele: (a) poreza na dohodak umanjenog za novčane naknade za obitelj (PITMFB), (b) doprinosa posloprimca, i (c) doprinosa poslodavca.

Grafikoni 6 do 9 uspoređuju dekompozicije poreznog klina za samačke hipotetske jedinice. Za samca bez djece s bruto plaćom od 67\% AGW-a (1A-67-NC, Grafikon 6) i samohranog roditelja s dvoje djece i istom razinom bruto plaće (1A-67-2C, Grafikon 7), vidljive su velike razlike kod udjela PITMFB-a u trošku rada, osobito u Irskoj, ali i u Nizozemskoj, Italiji i Hrvatskoj. Kao što je već spomenuto, na to utječu razlike u osobnom odbitku i umanjenju poreza te razlike u novčanim naknadama za obitelj.

\section{GRAFIKON 6.}

Dekompozicija neto prosječnog poreznog klina za hipotetsku jedinicu 1A-67-NC, 2013., u \%

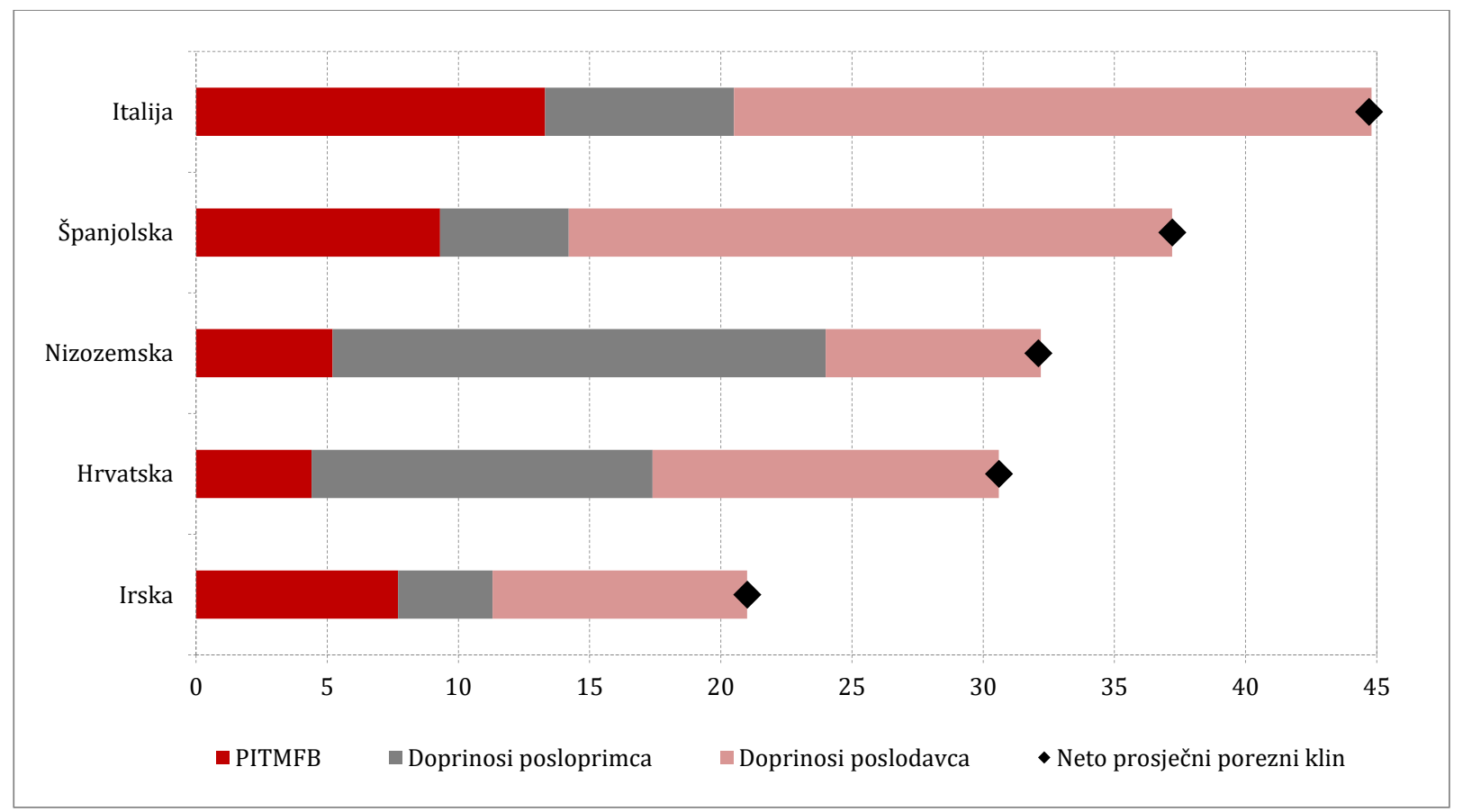

Izvor: autoričini izračuni na temelju OECD-a (2014.). 
GRAFIKON 7.

Dekompozicija neto prosječnog poreznog klina za hipotetsku jedinicu 1A-67-2C, 2013., u \%

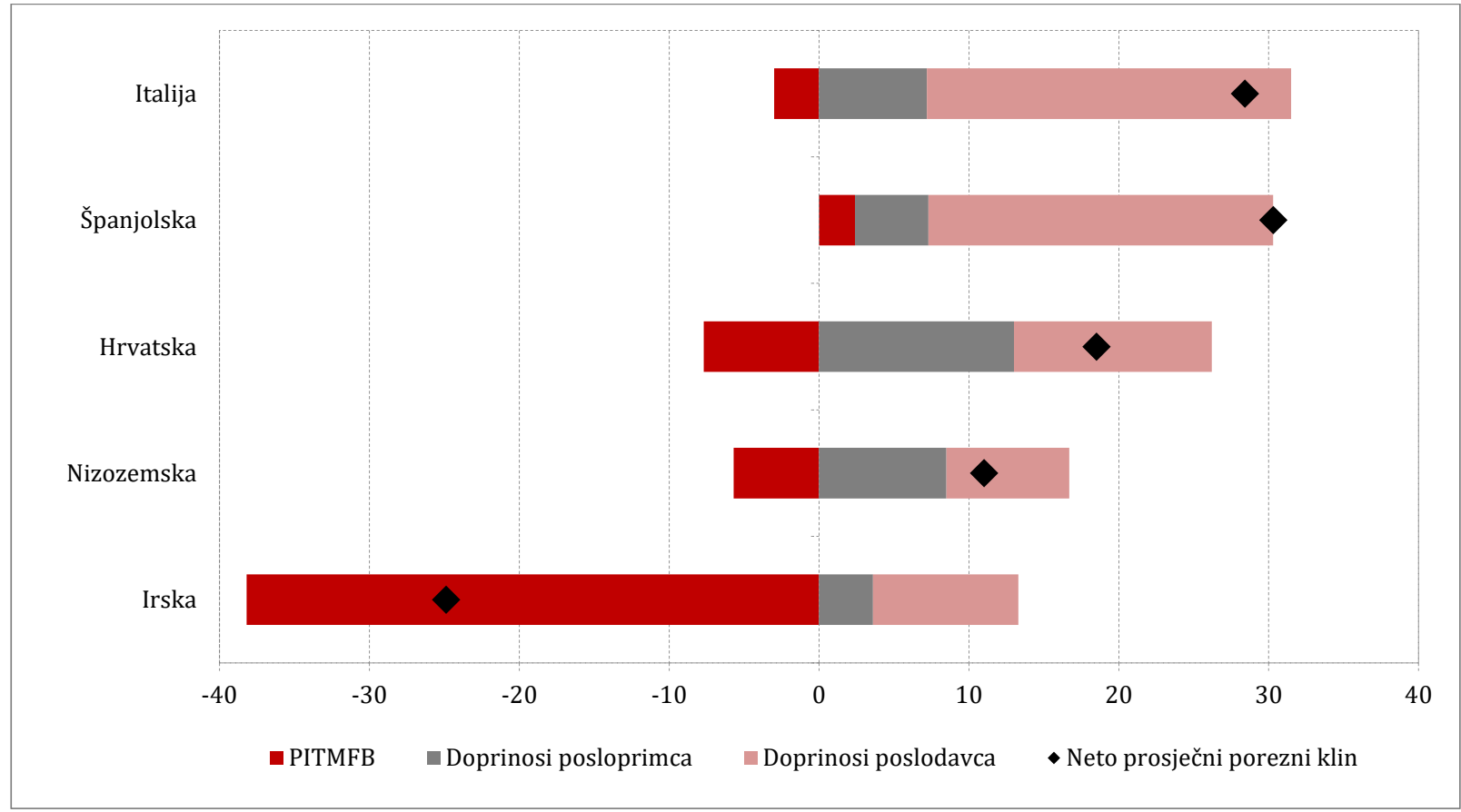

Izvor: autoričini izračuni na temelju OECD-a (2014.).

\section{GRAFIKON 8.}

Dekompozicija neto prosječnog poreznog klina za hipotetsku jedinicu 1A-100-NC, 2013., u \%

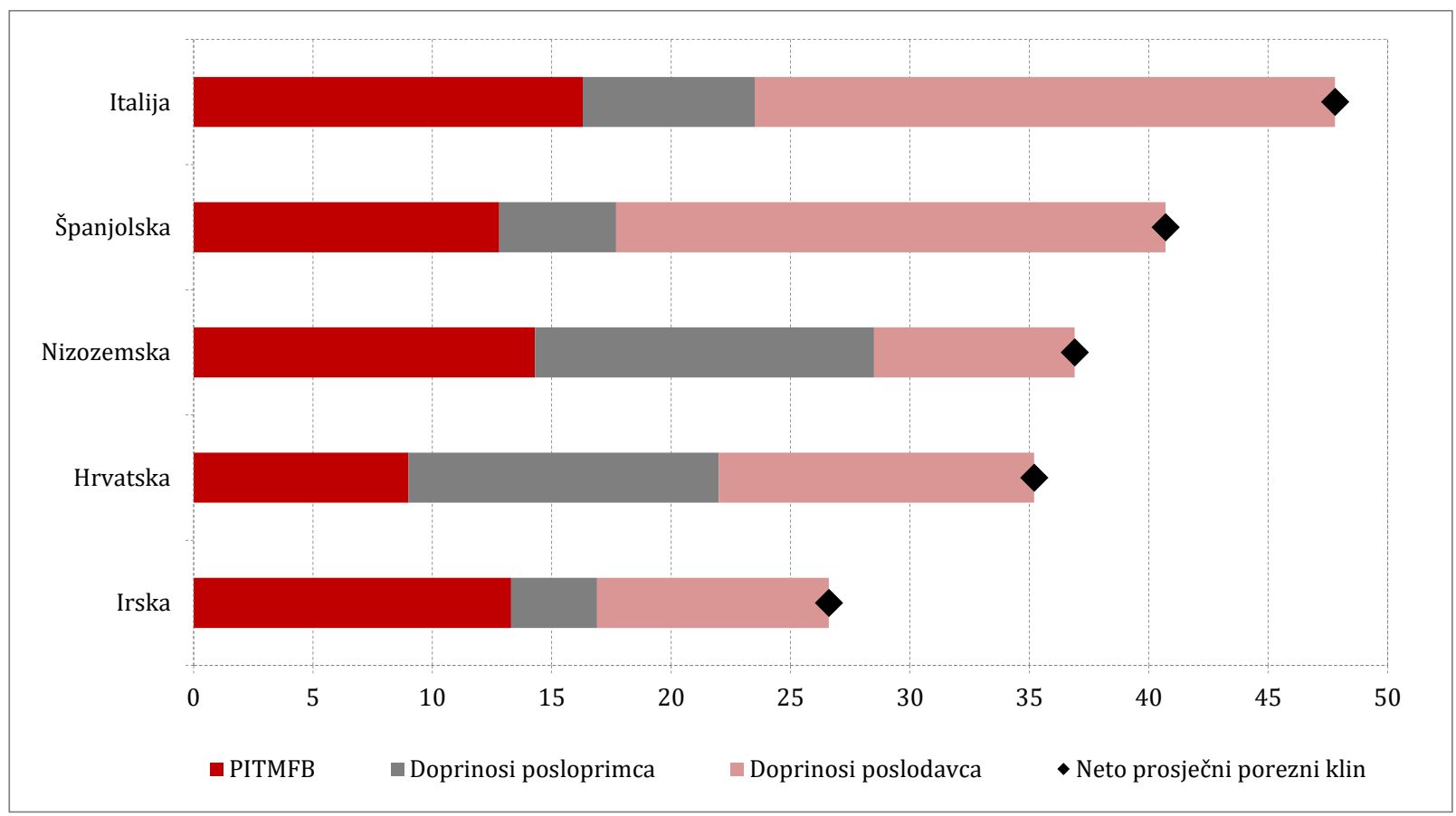

Izvor: autoričini izračuni na temelju OECD-a (2014.). 


\section{GRAFIKON 9.}

Dekompozicija neto prosječnog poreznog klina za hipotetsku jedinicu 1A-167-NC, 2013., u \%

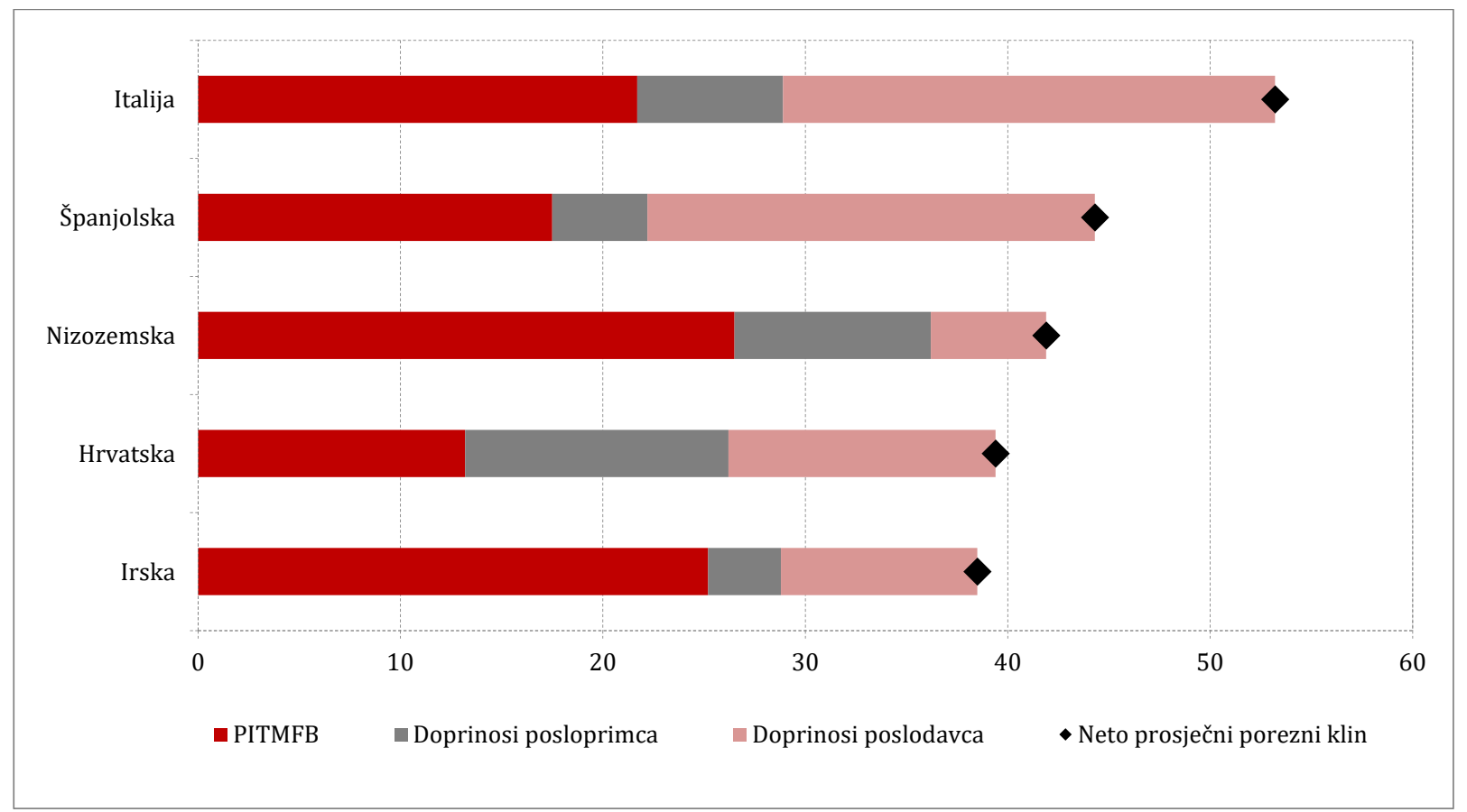

Izvor: autoričini izračuni na temelju OECD-a (2014.).

Usporede li se hipotetske jedinice bez djece s različitim razinama bruto plaće po spomenutim udjelima, očito je da je za talijanski najveći klin zaslužan upravo udio PITMFB-a. Jedino u posljednjem slučaju (1A-167-NC; Grafikon 9) najveći udio PITMFB-a ima Nizozemska. Po udjelu doprinosa posloprimca u trošku rada na prvom mjestu nalazi se Hrvatska, za gotovo svaku razinu bruto plaće, s 13\%. Udio doprinosa poslodavca u ukupnom trošku rada je najveći za Italiju te iznosi $24,3 \%$. Zatim slijedi Španjolska s $23 \%$, odnosno 22,1\% kod bruto plaće na razini od $167 \%$ AGW-a. U Hrvatskoj taj udio iznosi 13,2\%, u Irskoj 9,7\%, a u Nizozemskoj je promjenjiv, ovisno o razini plaće, ali u svakom slučaju manji od $9 \%$.

Grafikoni 10 do 13 uspoređuju dekompozicije poreznog klina za hipotetske jedinice parove.

Kod parova s dvoje djece (grafikoni 10, 11 i 12) najveći udio PITMFB-a u poreznom klinu ponovno ima Italija, osim kod 2A-100/0-2C (Grafikon 10), gdje je na prvom mjestu Nizozemska s 10,4\%. Kod 2A-100/0-2C, na drugom je mjestu Španjolska, a tek onda Italija. Par s djecom i najvećim dohotkom (2A-100/67-2C, Grafikon 11) ima najmanji udio PITMFB-a u Hrvatskoj, tek 3\%, zatim je u Irskoj malo veći, 5,8\% te je u Nizozemskoj i Španjolskoj redom 8,2\% i 9,7\%, a u Italiji iznosi 11,5\%. Doprinosi posloprimaca i dalje uzimaju najveći udio u Hrvatskoj, zatim u Nizozemskoj, Italiji, Španjolskoj, a najmanje u Irskoj. Udio doprinosa poslodavca i dalje je najveći u Italiji, u iznosu od 24,3\%. Slijedi Španjolska, a Hrvatska je s 13,2\% na trećem mjestu. Nizozemsku i Irsku karakteriziraju najmanji udjeli doprinosa poslodavca, i manji su od 10\%. 
GRAFIKON 10.

Dekompozicija neto prosječnog poreznog klina za hipotetsku jedinicu 2A-100/0-2C, 2013., u \%

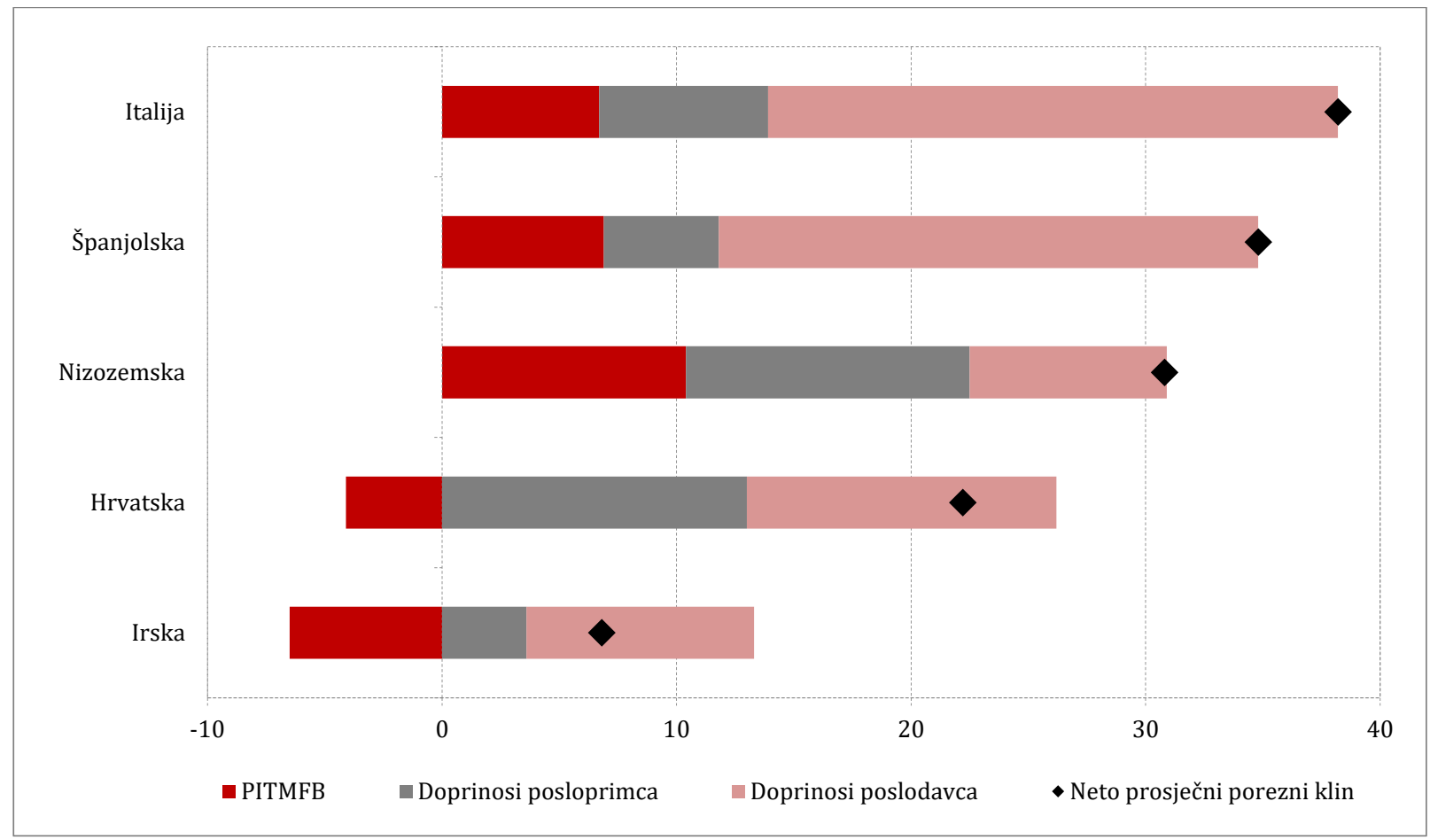

Izvor: autoričini izračuni na temelju OECD-a (2014.).

\section{GRAFIKON 11.}

Dekompozicija neto prosječnog poreznog klina za hipotetsku jedinicu 2A-100/67-2C, 2013., u \%

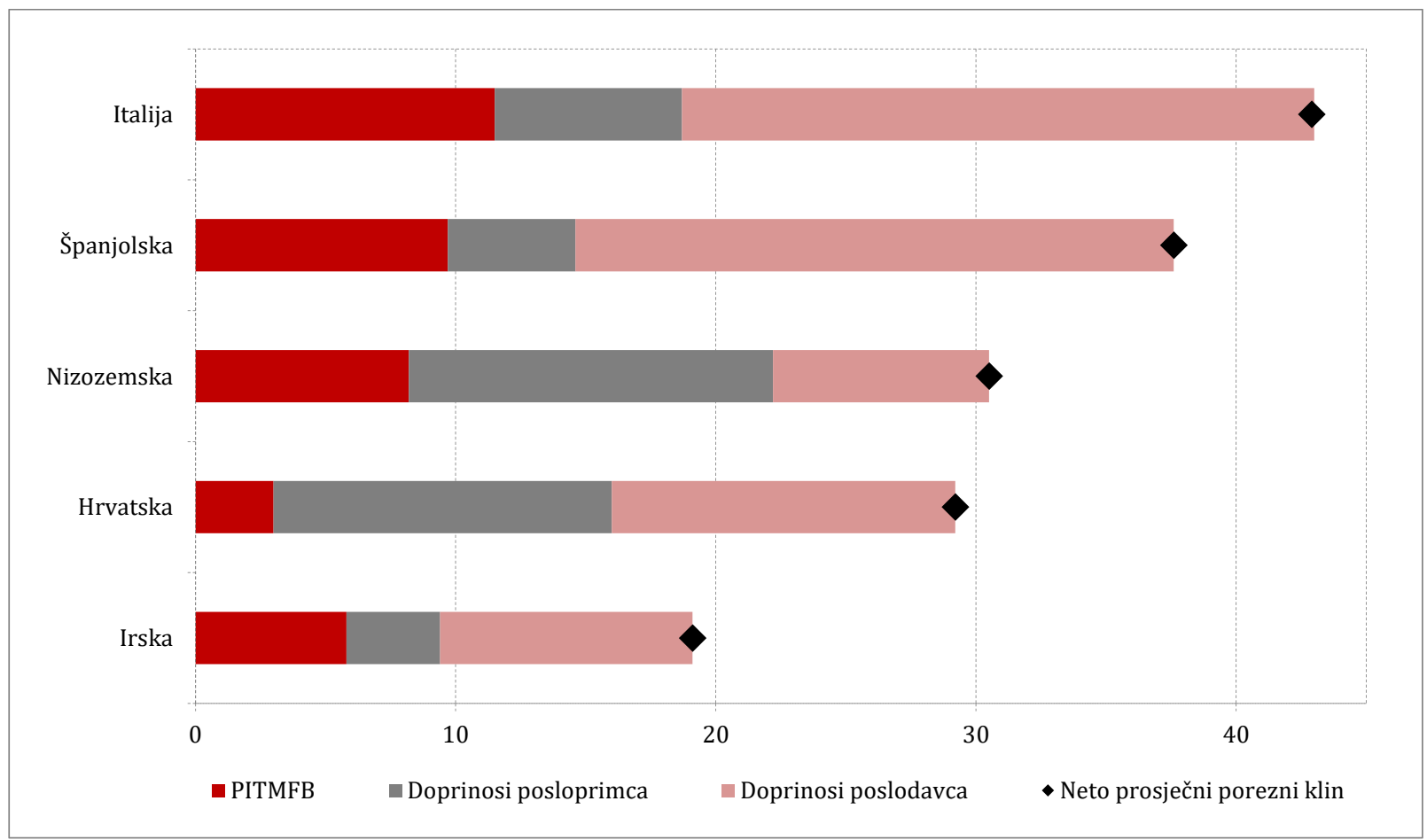

Izvor: autoričini izračuni na temelju OECD-a (2014.). 
GRAFIKON 12.

Dekompozicija neto prosječnog poreznog klina za hipotetsku jedinicu 2A-100/33-2C, 2013., u \%

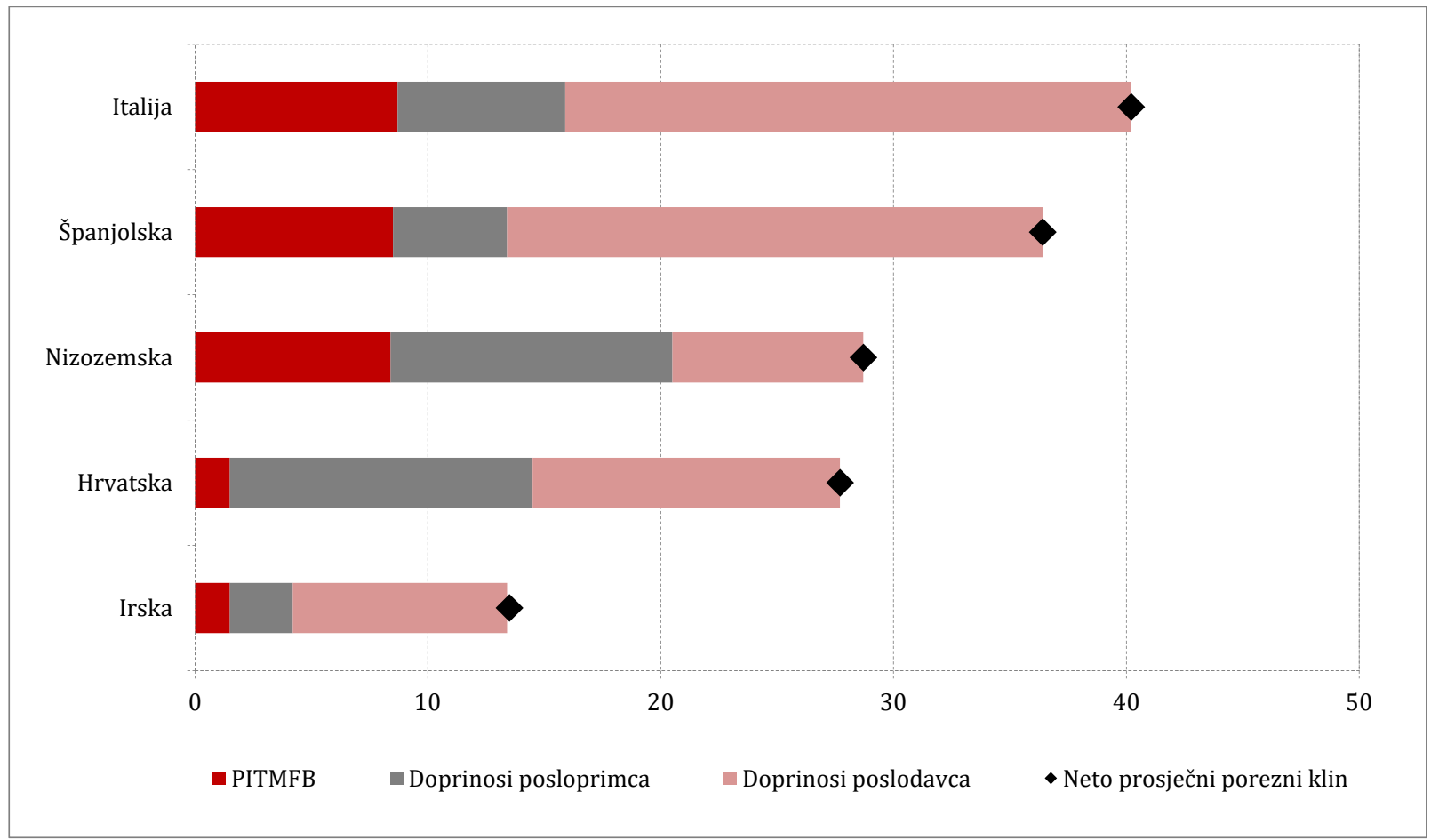

Izvor: autoričini izračuni na temelju OECD-a (2014.).

\section{GRAFIKON 13.}

Dekompozicija neto prosječnog poreznog klina (u \%) za hipotetsku jedinicu 2A-100/33-NC, 2013., u \%

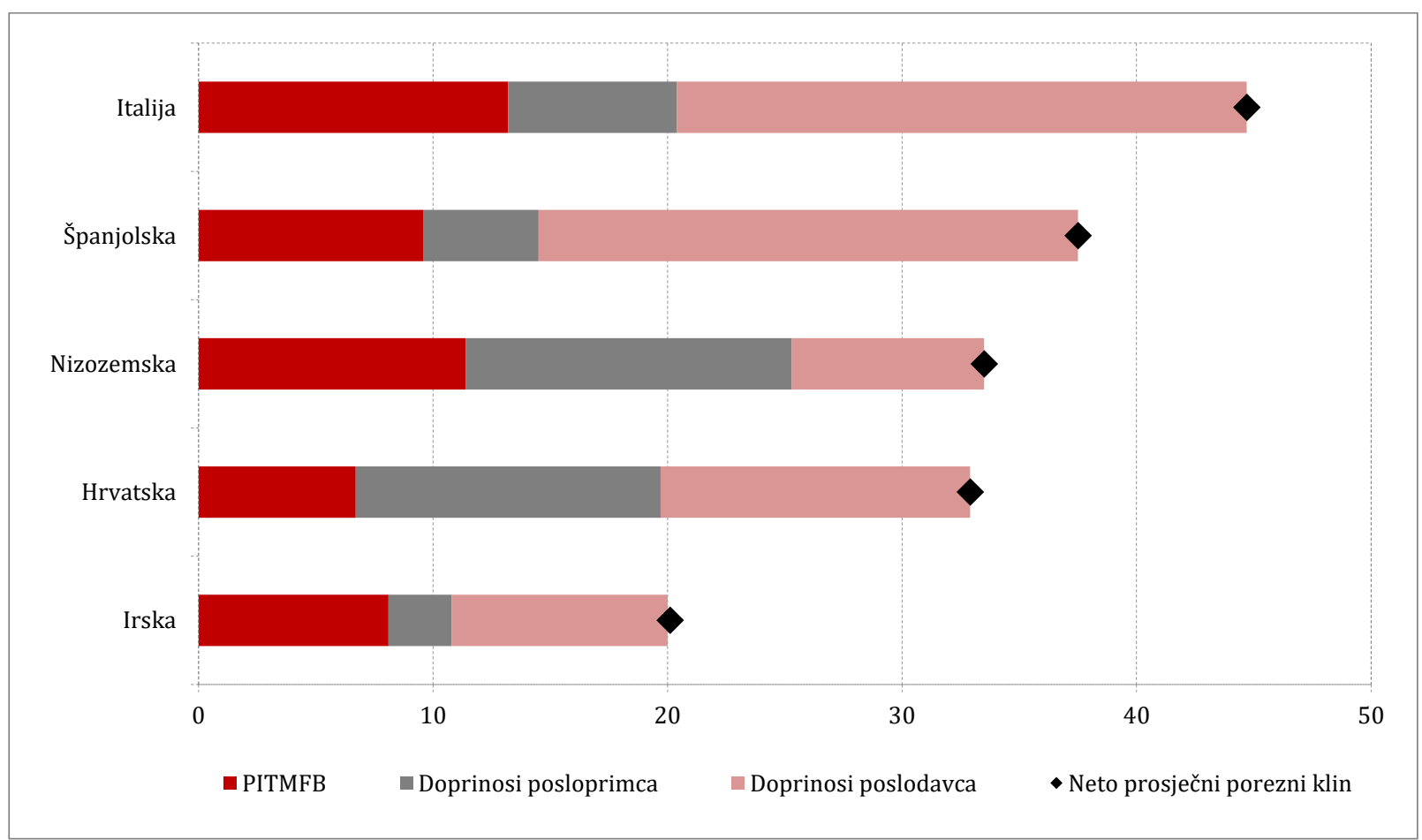

Izvor: autoričini izračuni na temelju OECD-a (2014.).

Grafikoni 12 i 13 prikazuju parove s istim bruto plaćama (2A-100/33-2C i 2A-100/33-NC), ali je drugi par bez djece pa je za očekivati da će porezni klin tog para uvijek biti veći u odnosu na prvi 
par. Najveća razlika vidi se u Irskoj, od 6,6 postotna boda, zatim u Hrvatskoj od 5,2 postotna boda, a u Španjolskoj se razlikuje tek za 1,1 postotna boda.

Nizozemska se razlikuje od ostalih zemalja po tome što se porezni klin smanjuje s $30,8 \%$ kod para s dvoje djece i prihodima od 100 i 0\% AGW-a (2A-100/0-2C), na 28,7\% kod para s dvoje djece i prihodima od 100 i 33\% AGW-a (2A-100/33-2C), kada opet poraste na 30,5\% kod para s dvoje djece i bruto plaćama na razini od 100 i 67\% AGW-a (2A-100/67-2C).

Najveći porezni klin ima Italija, a najmanji Irska za skoro svaku promatranu razinu bruto plaće, dok se Hrvatska smjestila na srednje mjesto u većini slučajeva.

\section{ZAKLJUČAK}

U radu su se uspoređivali pokazatelji poreznog opterećenja za različite tipove obitelji u Hrvatskoj, Italiji, Španjolskoj, Irskoj i Nizozemskoj. Rezultati pokazuju da Italija nedvojbeno ostvaruje najveći neto prosječni porezni klin, gotovo za svaki promatrani tip obitelji. Sjeverozapadne europske zemlje, Nizozemska i Irska, odlikuju se niskim poreznim klinom, osobito Irska.

Manje neto prosječne porezne stope i manji porezni klin mogu značiti bolju gospodarsku situaciju zemlje naspram zemlje u kojoj je porezno opterećenje građana veće. Dakako, manji porezni klin ne mora biti nužan uvjet zadovoljstva među građanima, jer oni mogu biti zadovoljni i s većim davanjima ako im država zauzvrat pruža javne usluge i dobra koje oni smatraju zadovoljavajućima. Koliko će pojedinac u nekoj zemlji morati izdvajati iz svojih primanja u svrhu poreza ili nekih drugih davanja, može ovisiti o puno različitih faktora, ali ipak će većini građana biti draže ako od plaće može više zadržati za vlastitu nego državnu potrošnju. No, vlastita potrošnja opet će značiti u konačnici povećanje državnih prihoda putem drugih vrsta poreza, pa prema tome ostaje upitno koji je porezni klin optimalan. 


\section{REFERENCE}

1. Anon, 2016. Kako izračunati plaću...? Što je to tax credit, pay slip, PRSI, USC...? [online] Život u Dublinu. Dostupno na: <http://zivot-u-dublinu.com/kako-izracunati-placu-sto-je-to-taxcredit-pay-slip-prsi-usc/>.

2. Blažić, H. i Trošelj, I., 2012. Međunarodna usporedba poreznog opterećenja radne snage: utjecaj nove metodologije na položaj Hrvatske. U: L. Božina, M. Gonan-Božac i D. Učkar, ur. Financije i menadžment u globalnoj ekonomiji. Pula: Sveučilište Jurja Dobrile u Puli, Odjel za ekonomiju i turizam, str. 185-204.

3. DZS, 2014. Prosječna mjesečna isplaćena neto-plaća po zaposlenome u pravnim osobama Republike Hrvatske za 2013. i Prosječna mjesečna bruto-plaća po zaposlenome u pravnim osobama Republike Hrvatske za 2013. [online] Dostupno na: <http://narodnenovine.nn.hr/clanci/sluzbeni/2014_03_32_596.html>.

4. DZS, 2016. Statistika u nizu: Zaposlenost $i$ plaće. [online] Dostupno na: <http://www.dzs.hr/Hrv_Eng/Pokazatelji/MSI ZAPOSLENOST I PLACE.xlsx>.

5. HNB, 2016. CNB midpoint exchange rate. [online] Dostupno na: <http://www.en/statistics/statistical-data/central-bank-cnb/cnb-midpoint-exchange-rate>

6. Čok, M. [et al.], 2013. Taxation of wages in the Alps-Adriatic region. Financial Theory and Practice, 37(3), str. 259-277. Dostupno na: <http://hrcak.srce.hr/107921?lang=en>.

7. de Vos, K. i de Agostini, P., 2014. EUROMOD Country Report: Netherlands. [online] Dostupno na: <https://www.iser.essex.ac.uk/files/euromod/countryreports/Year5/CR_NL_2009_13_Final. pdf>.

8. HZMO, 2016. Cenzusi i svote doplatka za djecu. [online] Dostupno na: <http://www.mirovinsko.hr/default.aspx?ID=100>.

9. IJF, 2016. Leksikon javnih financija. [online] Dostupno na: <http://www.ijf.hr/hr/korisneinformacije/leksikon-javnih-financija/14/>.

10. O’Donoghue, C., 2014. EUROMOD Country Report: Ireland 2009-2013. [online] Dostupno na: $<$ https://www.iser.essex.ac.uk/files/euromod/countryreports/Year5/CR_IE_Year5_01082014.pdf>

11. OECD, 2014. Taxing Wages 2014. Paris: OECD.

12. Urban, I., 2014. Supports for households with children. Newsletter, br. 88. [online] Dostupno na: <http://www.ijf.hr/upload/files/file/ENG/newsletter/88.pdf>.

13. Urban, I., 2016. Tax wedge on labour income in Croatia and the European Union. Financial Theory and Practice, 40(2), str. 157-168. doi: 10.3326/fintp.40.2.1

14. Zakon o izmjenama i dopunama Zakona o doprinosima, NN 22/12. [online] Dostupno na: <http://narodne-novine.nn.hr/clanci/sluzbeni/2012_02_22_572.html>.

15. Zakon o minimalnoj plaći, NN 39/13. [online] Dostupno na: <http://narodnenovine.nn.hr/clanci/sluzbeni/2013_04_39_720.html>.

16. Zakon o porezu na dohodak, NN 177/04., 73/08., 80/10., 114/11., 22/12., 144/12., 43/13., 120/13., 125/13., 148/13., 83/14., 143/14. [online] Dostupno na: <http://www.zakon.hr/z/85/Zakon-o-porezu-na-Personal income>. 


\section{DODATAK \\ IZRAČUN POKAZATELJA POREZNOG OPTEREĆENJA ZA HIPOTETSKE JEDINICE U ODABRANIM ZEMLJAMA}

\section{HRVATSKA}

\section{TABLICA A1.}

Izračun pokazatelja poreznog opterećenja za hipotetske jedinice: samce (Hrvatska, 2013.)

\begin{tabular}{|c|c|c|c|c|}
\hline & 1A-67-NC & 1A-100-NC & 1A-167-NC & $1 A-67-2 C$ \\
\hline 1. Bruto plaća (u eurima) & 8.202 & 12.303 & 20.505 & 8.202 \\
\hline 2. Doprinosi poslodavca & 1.247 & 1.870 & 3.117 & 1.247 \\
\hline 3. Doprinosi posloprimca & 1.640 & 2.461 & 4.101 & 1.640 \\
\hline 3.1. prvi stup mir. osig. & 1.230 & 1.845 & 3.076 & 1.230 \\
\hline 3.2. drugi stup mir. osig. & 410 & 615 & 1.025 & 410 \\
\hline \multicolumn{5}{|l|}{ 4. Troškovi vezani uz rad } \\
\hline \multicolumn{5}{|l|}{ 5. Olakšica } \\
\hline 6. Dohodak & 6.562 & 9.842 & 16.404 & 6.562 \\
\hline 7. Osobni odbitak & 3.486 & 3.486 & 3.486 & 7.671 \\
\hline 8. Porezna osnovica & 3.076 & 6.357 & 12.918 & 0 \\
\hline 9. Porez na dohodak & 369 & 1.136 & 2.776 & 0 \\
\hline \multicolumn{5}{|l|}{ 10.Umanjenje poreza } \\
\hline 11.Porez nakon umanjenja & 369 & 1.136 & 2.776 & 0 \\
\hline 12.Lokalni porezi (prirez od 12\%) & 44 & 136 & 333 & 0 \\
\hline 13. Ukupno porezi & 413 & 1.272 & 3.110 & 0 \\
\hline 14. Novčane naknade za obitelj & 0 & 0 & 0 & 727 \\
\hline 15. Neto plaća & 6.148 & 8.570 & 13.294 & 6.562 \\
\hline 16. Trošak rada & 9.449 & 14.173 & 23.622 & 9.449 \\
\hline 17. Ukupno porezi i doprinosi & 3.300 & 5.603 & 10.327 & 2.887 \\
\hline 17.1. porezna davanja & 2.890 & 4.987 & 9.303 & 1.750 \\
\hline 17.2. neporezna davanja & 410 & 615 & 1.025 & 410 \\
\hline 18. Neto prosječna porezna stopa (\%) & 20,0 & 25,3 & 30,2 & 6,1 \\
\hline 19. Neto prosječni porezni klin (\%) & 30,6 & 35,2 & 39,4 & 18,5 \\
\hline
\end{tabular}

Napomena: doprinosi posloprimca za drugi stup mirovinskog osiguranja ne ulaze u porezna davanja prema Taxing Wages metodologiji (OECD, 2014.). Stoga je stavka 17. podijeljena na podstavke porezna (17.1.) i neporezna (17.2.) davanja, pri čemu samo porezna davanja ulaze u izračun pokazatelja poreznog opterećenja.

Izvor: autoričini izračuni. 
TABLICA A2.

Izračun pokazatelja poreznog opterećenja za hipotetske jedinice: parove (Hrvatska, 2013.)

2A-100/0-2C 2A-100/33-2C 2A-100/67-2C 2A-100/33-NC

\begin{tabular}{|c|c|c|c|c|}
\hline 1. Bruto plaća (u eurima) & 12.303 & 16.404 & 20.505 & 16.404 \\
\hline 2. Doprinosi poslodavca & 1.870 & 2.493 & 3.117 & 2.493 \\
\hline 3. Doprinosi posloprimca & 2.461 & 3.281 & 4.101 & 3.281 \\
\hline 3.1. prvi stup mir. osig. & 1.845 & 2.461 & 3.076 & 2.461 \\
\hline 3.2. drugi stup mir. osig. & 615 & 820 & 1.025 & 820 \\
\hline \multicolumn{5}{|l|}{ 4. Troškovi vezani za rad } \\
\hline \multicolumn{5}{|l|}{ 5. Olakšica } \\
\hline 6. Dohodak & 9.842 & 13.123 & 16.404 & 13.123 \\
\hline 7. Osobni odbitak & 9.412 & 11.155 & 11.155 & 6.972 \\
\hline 8. Porezna osnovica & 431 & 2.174 & 5.249 & 6.357 \\
\hline 9. Porez na dohodak & 52 & 261 & 630 & 1.136 \\
\hline \multicolumn{5}{|l|}{ 10.Umanjenje poreza } \\
\hline 11. Porez nakon umanjenja & 52 & 261 & 630 & 1.136 \\
\hline $\begin{array}{l}\text { 12. Lokalni porezi (prirez od } \\
12 \% \text { ) }\end{array}$ & 6 & 31 & 76 & 136 \\
\hline 13. Ukupno porezi & 58 & 292 & 706 & 1.272 \\
\hline 14. Novčane naknade za obitelj & 632 & 0 & 0 & 0 \\
\hline 15. Neto plaća & 9.785 & 12.831 & 15.698 & 11.851 \\
\hline 16. Trošak rada & 14.173 & 18.897 & 24.161 & 18.897 \\
\hline 17. Ukupno porezi i doprinosi & 3.756 & 6.066 & 7.923 & 7.047 \\
\hline 17.1. porezna davanja & 3.141 & 5.246 & 6.899 & 6.226 \\
\hline 17.2. neporezna davanja & 615 & 820 & 1025 & 820 \\
\hline $\begin{array}{l}\text { 18. Neto prosječna porezna } \\
\text { stopa (\%) }\end{array}$ & 10,3 & 16,8 & 18,4 & 22,8 \\
\hline $\begin{array}{l}\text { 19. Neto prosječni porezni klin } \\
(\%)\end{array}$ & 22,2 & 27,8 & 29,2 & 32,9 \\
\hline
\end{tabular}

Napomena: vidjeti napomenu uz tablicu A1.

Izvor: autoričini izračuni. 


\section{ITALIJA}

TABLICA A3.

Izračun pokazatelja poreznog opterećenja za hipotetske jedinice: samce (Italija, 2013.)

\begin{tabular}{|c|c|c|c|c|}
\hline & 1A-67-NC & 1A-100-NC & 1A-167-NC & $1 A-67-2 C$ \\
\hline 1. Bruto plaća (u eurima) & 19.802 & 29.704 & 49.506 & 19.802 \\
\hline 2. Doprinosi poslodavca & 6.353 & 9.529 & 15.882 & 6.353 \\
\hline 3. Doprinosi posloprimca & 1.879 & 2.819 & 4.738 & 1.879 \\
\hline 4. Troškovi vezani uz rad & - & - & - & - \\
\hline 5. Olakšice & - & - & - & - \\
\hline 6. Dohodak & 17.923 & 26.885 & 44.768 & 17.923 \\
\hline 7. Osobni odbitak & - & - & - & - \\
\hline 8. Porezna osnovica & 17.923 & 26.885 & 44.768 & 17.923 \\
\hline 9. Porez na dohodak & 4.239 & 6.659 & 13.332 & 4.239 \\
\hline 10. Umanjenje poreza & 1.240 & 969 & 342 & 2.831 \\
\hline 11. Porez nakon umanjenja & 2.999 & 5.690 & 12.990 & 1.409 \\
\hline 12. Lokalni porezi & 471 & 707 & 1.177 & 471 \\
\hline 13. Ukupno porezi & 3.470 & 6.397 & 14.167 & 1.880 \\
\hline 14. Novčane naknade za obitelj & 0 & 0 & 0 & 2.671 \\
\hline 15. Neto plaća & 11.453 & 20.487 & 30.601 & 18.714 \\
\hline 16. Trošak rada & 26.155 & 39.233 & 65.388 & 26.155 \\
\hline 17. Ukupno porezi i doprinosi & 11.703 & 18.745 & 34.787 & 10.112 \\
\hline 18. Neto prosječna porezna stopa (\%) & 27,0 & 31,0 & 38,2 & 5,5 \\
\hline 19. Neto prosječni porezni klin (\%) & 44,7 & 47,8 & 53,2 & 28,4 \\
\hline
\end{tabular}

Izvor: autoričini izračuni na temelju OECD-a (2014.). 
TABLICA A4.

Izračun pokazatelja poreznog opterećenja za hipotetske jedinice: parove (Italija, 2013.)

$2 A-100 / 0-2 C \quad 2 A-100 / 33-2 C \quad 2 A-100 / 67-2 C \quad 2 A-100 / 33-N C$

\begin{tabular}{|c|c|c|c|c|}
\hline 1. Bruto plaća (u eurima) & 29.704 & 39.605 & 49.506 & 39.605 \\
\hline 2. Doprinosi poslodavca & 9.529 & 12.705 & 15.882 & 12.705 \\
\hline 3. Doprinosi posloprimca & 2.819 & 3.758 & 4.698 & 3.758 \\
\hline 4. Troškovi vezani uz rad & - & - & - & - \\
\hline 5. Olakšice & - & - & - & - \\
\hline 6. Dohodak & 26.885 & 35.846 & 44.808 & 35.846 \\
\hline 7. Osobni odbitak & - & - & - & - \\
\hline 8. Porezna osnovica & 26.885 & 35.846 & 44.808 & 35.846 \\
\hline 9. Porez na dohodak & 6.659 & 8.720 & 10.898 & 8.720 \\
\hline 10. Umanjenje poreza & 3.094 & 4.175 & 3.722 & 2.740 \\
\hline 11. Porez nakon umanjenja & 3.565 & 4.545 & 7.176 & 5.980 \\
\hline 12. Lokalni porezi & 707 & 943 & 1.178 & 943 \\
\hline 13. Ukupno porezi & 4.272 & 5.488 & 8.354 & 6.923 \\
\hline $\begin{array}{l}\text { 14. Novčane naknade za } \\
\text { obitelj }\end{array}$ & 1.644 & 932 & 861 & 0 \\
\hline 15. Neto plaća & 24.257 & 31.290 & 37.314 & 28.923 \\
\hline 16. Trošak rada & 39.233 & 52.310 & 65.388 & 52.310 \\
\hline 17. Ukupno porezi i doprinosi & 16.620 & 21.951 & 28.934 & 23.387 \\
\hline $\begin{array}{l}\text { 18. Neto prosječna porezna } \\
\text { stopa }(\%)\end{array}$ & 18,3 & 21,0 & 24,6 & 27,0 \\
\hline $\begin{array}{l}\text { 19. Neto prosječni porezni } \\
\text { klin }(\%)\end{array}$ & 38,2 & 40,2 & 42,9 & 44,7 \\
\hline
\end{tabular}

Izvor: autoričini izračuni na temelju OECD-a (2014.). 


\section{ŠPANJOLSKA}

TABLICA A5.

Izračun pokazatelja poreznog opterećenja za hipotetske jedinice: samce (Španjolska, 2013.)

\begin{tabular}{lrrrr} 
& 1A-67-NC & 1A-100-NC & 1A-167-NC & 1A-67-2C \\
\hline 1. Bruto plaća (u eurima) & 17.351 & 26.027 & 43.378 & 17.351 \\
\hline 2. Doprinosi poslodavca & 5.188 & 7.782 & 12.291 & 5.188 \\
\hline 3. Doprinosi posloprimca & 1.102 & 1.653 & 2.610 & 1.102 \\
\hline 4. Troškovi vezani uz rad & 2.652 & 2.652 & 2.652 & 2.652 \\
\hline 5. Olakšice & 0 & 0 & 0 & 2.150 \\
\hline 6. Dohodak & 13.597 & 21.722 & 38.116 & 11.447 \\
\hline 7. Osobni odbitak & & - & - & - \\
\hline 8. Porezna osnovica & 13.597 & 21.722 & 38.116 & 11.447 \\
\hline 9. Porez na dohodak & 3.365 & 5.587 & 11.016 & 2.833 \\
\hline 10. Umanjenje poreza & 1.275 & 1.275 & 1.275 & 2.289 \\
\hline 11. Porez nakon umanjenja & 2.091 & 4.312 & 9.741 & 543 \\
\hline 12. Lokalni porezi & & - & - & - \\
\hline 13. Ukupno porezi & 2.091 & 4.312 & 9.741 & 543 \\
\hline 14. Novčane naknade za obitelj & 0 & 0 & & 0 \\
\hline 15. Neto plaća & 14.159 & 20.062 & 31.027 & 15.706 \\
\hline 16. Trošak rada & 22.539 & 33.809 & 55.670 & 22.539 \\
\hline 17. Ukupno porezi i doprinosi & 8.380 & 13.747 & 24.643 & 6.834 \\
\hline 18. Neto prosječna porezna stopa (\%) & 18,4 & 22,9 & 28,5 & 9,5 \\
\hline 19. Neto prosječni porezni klin (\%) & 37,2 & 40,7 & 44,3 & 30,3 \\
\hline
\end{tabular}

Izvor: autoričini izračuni na temelju OECD-a (2014.). 
TABLICA 156.

Izračun pokazatelja poreznog opterećenja za hipotetske jedinice: parove (Španjolska, 2013.)

$2 A-100 / 0-2 C \quad 2 A-100 / 33-2 C \quad 2 A-100 / 67-2 C \quad 2 A-100 / 33-N C$

\begin{tabular}{|c|c|c|c|c|}
\hline 1. Bruto plaća (u eurima) & 26.027 & 34.703 & 43.378 & 34.703 \\
\hline 2. Doprinosi poslodavca & 7.782 & 10.376 & 12.970 & 10.376 \\
\hline 3. Doprinosi posloprimca & 1.653 & 2.204 & 2.755 & 2.204 \\
\hline 4. Troškovi vezani uz rad & 2.652 & 6.732 & 5.304 & 6.732 \\
\hline 5. Olakšice & 3.400 & 0 & 0 & 0 \\
\hline 6. Dohodak & 18.322 & 25.767 & 35.320 & 25.767 \\
\hline \multicolumn{5}{|l|}{ 7. Osobni odbitak } \\
\hline 8. Porezna osnovica & 18.322 & 25.767 & 35.320 & 25.767 \\
\hline 9. Porez na dohodak & 4.567 & 6.588 & 8.952 & 6.588 \\
\hline 10. Umanjenje poreza & 2.234 & 2.756 & 3.509 & 2.276 \\
\hline 11. Porez nakon umanjenja & 2.333 & 3.832 & 5.443 & 4.312 \\
\hline \multicolumn{5}{|l|}{ 12. Lokalni porezi } \\
\hline 13. Ukupno porezi & 2.333 & 3.832 & 5.443 & 4.312 \\
\hline $\begin{array}{l}\text { 14. Novčane naknade za } \\
\text { obitelj }\end{array}$ & 0 & 0 & 0 & 0 \\
\hline 15. Neto plaća & 22.041 & 28.666 & 35.180 & 28.187 \\
\hline 16. Trošak rada & 33.809 & 45.079 & 56.348 & 45.079 \\
\hline 17. Ukupno porezi i doprinosi & 11.768 & 16.412 & 21.168 & 16.892 \\
\hline $\begin{array}{l}\text { 18. Neto prosječna porezna } \\
\text { stopa }(\%)\end{array}$ & 15,3 & 17,4 & 18,9 & 18,8 \\
\hline $\begin{array}{l}\text { 19. Neto prosječni porezni } \\
\text { klin }(\%)\end{array}$ & 34,8 & 36,4 & 37,6 & 37,5 \\
\hline
\end{tabular}

Izvor: autoričini izračuni na temelju OECD-a (2014.). 


\section{IRSKA}

TABLICA A7.

Izračun pokazatelja poreznog opterećenja za hipotetske jedinice: samce (Irska, 2013.)

\begin{tabular}{lrrrr} 
& 1A-67-NC & 1A-100-NC & 1A-167-NC & 1A-67-2C \\
\hline 1. Bruto plaća (u eurima) & 21.587 & 32.381 & 53.968 & 21.587 \\
\hline 2. Doprinosi poslodavca & 2.321 & 3.481 & 5.802 & 2.321 \\
\hline 3. Doprinosi posloprimca & 863 & 1.295 & 2.159 & 863 \\
\hline 4. Troškovi vezani uz rad & & & & \\
\hline 5. Olakšice & & & & \\
\hline 6. Dohodak & 21.587 & 32.381 & 53.968 & 21.587 \\
\hline 7. Osobni odbitak & & & & \\
\hline 8. Porezna osnovica & 21.587 & 32.381 & 53.968 & 21.587 \\
\hline 9. Porez na dohodak & 4.317 & 6.476 & 15.239 & 4.317 \\
\hline 10. Umanjenje poreza & 3.300 & 3.300 & 3.300 & 4.950 \\
\hline 11. Porez nakon umanjenja & 1.017 & 3.176 & 11.939 & 0 \\
\hline 12. Lokalni porezi (USC) & 830 & 1.585 & 3.097 & 830 \\
\hline 13. Ukupno porezi & 1.847 & 4.762 & 15.036 & 830 \\
\hline 14. Novčane naknade za obitelj & 0 & 0 & & 9.966 \\
\hline 15. Neto plaća & 18.876 & 26.324 & 36.774 & 29.860 \\
\hline 16. Trošak rada & 23.908 & 35.862 & 59.770 & 23.908 \\
\hline 17. Ukupno porezi i doprinosi & 5.031 & 9.538 & 22.996 & 4.014 \\
\hline 18. Neto prosječna porezna stopa (\%) & 12,6 & 18,7 & 31,9 & $-38,3$ \\
\hline 19. Neto prosječni porezni klin (\%) & 21 & 26,6 & 38,5 & $-24,9$ \\
\hline
\end{tabular}

Izvor: autoričini izračuni na temelju OECD-a (2014.). 
TABLICA A8.

Izračun pokazatelja poreznog opterećenja za hipotetske jedinice: parove (Irska, 2013.)

2A-100/0-2C 2A-100/33-2C 2A-100/67-2C 2A-100/33-NC

\begin{tabular}{|c|c|c|c|c|}
\hline 1. Bruto plaća (u eurima) & 32.381 & 43.175 & 53.968 & 43.175 \\
\hline 2. Doprinosi poslodavca & 3.481 & 4.398 & 5.802 & 4.398 \\
\hline 3. Doprinosi posloprimca & 1.295 & 1.295 & 2.159 & 1.295 \\
\hline \multicolumn{5}{|l|}{ 4. Troškovi vezani uz rad } \\
\hline \multicolumn{5}{|l|}{ 5. Olakšice } \\
\hline 6. Dohodak & 32.381 & 43.175 & 53.968 & 43.175 \\
\hline \multicolumn{5}{|l|}{ 7. Osobni odbitak } \\
\hline 8. Porezna osnovica & 32.381 & 43.175 & 53.968 & 43.175 \\
\hline 9. Porez na dohodak & 6.476 & 8.635 & 10.794 & 8.635 \\
\hline 10.Umanjenje poreza & 5.760 & 6.600 & 6.600 & 6.600 \\
\hline 11. Porez nakon umanjenja & 716 & 2.035 & 4.194 & 2.035 \\
\hline 12. Lokalni porezi & 1.585 & 1.816 & 2.415 & 1.816 \\
\hline 13. Ukupno porezi & 2.302 & 3.851 & 6.609 & 3.851 \\
\hline $\begin{array}{l}\text { 14. Novčane naknade za } \\
\text { obitelj }\end{array}$ & 4.632 & 3.120 & 3.120 & 0 \\
\hline 15. Neto plaća & 33.416 & 41.148 & 48.320 & 38.028 \\
\hline 16. Trošak rada & 35.862 & 47.573 & 59.770 & 47.573 \\
\hline 17. Ukupno porezi i doprinosi & 7.078 & 9.544 & 14.569 & 9.544 \\
\hline $\begin{array}{l}\text { 18. Neto prosječna porezna } \\
\text { stopa }(\%)\end{array}$ & $-3,2$ & 4,7 & 10,5 & 11,9 \\
\hline $\begin{array}{l}\text { 19. Neto prosječni porezni } \\
\text { klin }(\%)\end{array}$ & 6,8 & 13,5 & 19,2 & 20,1 \\
\hline
\end{tabular}

Izvor: autoričini izračuni na temelju OECD-a (2014.). 


\section{NIZOZEMSKA}

TABLICA A9.

Izračun pokazatelja poreznog opterećenja za hipotetske jedinice: samce (Nizozemska, 2013.)

\begin{tabular}{lrrrr} 
& 1A-67-NC & 1A-100-NC & 1A-167-NC & 1A-67-2C \\
\hline 1. Bruto plaća (u eurima) & 32.073 & 48.109 & 80.182 & 32.073 \\
\hline 2. Doprinosi poslodavca & 2.862 & 4.405 & 4.864 & 2.862 \\
\hline 3. Doprinosi posloprimca & 6.562 & 7.462 & 8.245 & 2.985 \\
\hline 4. Troškovi vezani uz rad & & & & \\
\hline 5. Olakšice & 2.413 & 3.590 & 3.941 & 2.413 \\
\hline 6. Dohodak & 31.129 & 46.328 & 76.727 & 31.129 \\
\hline 7. Osobni odbitak & & & & \\
\hline 8. Porezna osnovica & 31.129 & 46.328 & 76.727 & 31.129 \\
\hline 9. Porez na dohodak & 2.395 & 8.083 & 22.924 & 2.395 \\
\hline 10. Umanjenje poreza & 589 & 550 & 403 & 1.355 \\
\hline 11. Porez nakon umanjenja & 1.806 & 7.533 & 22.521 & 1.040 \\
\hline 12. Lokalni porezi & & & & \\
\hline 13. Ukupno porezi & 1.806 & 7.533 & 22.521 & 1.040 \\
\hline 14. Novčane naknade za obitelj & 0 & 0 & & 3.035 \\
\hline 15. Neto plaća & 23.705 & 33.114 & 49.416 & 31.083 \\
\hline 16. Trošak rada & 34.935 & 52.514 & 85.046 & 34.935 \\
\hline 17.Ukupno porezi i doprinosi & 11.230 & 19.400 & 35.630 & 6.887 \\
\hline 18. Neto prosječna porezna stopa (\%) & 26,1 & 31,2 & 38,4 & 3,1 \\
\hline 19. Neto prosječni porezni klin (\%) & 32,1 & 36,9 & 41,9 & 11,0 \\
\hline
\end{tabular}

Izvor: autoričini izračuni na temelju OECD-a (2014.). 
TABLICA A10.

Izračun pokazatelja poreznog opterećenja za hipotetske jedinice: parove (Nizozemska, 2013.)

$2 A-100 / 0-2 C \quad 2 A-100 / 33-2 C \quad 2 A-100 / 67-2 C \quad 2 A-100 / 33-N C$

\begin{tabular}{|c|c|c|c|c|}
\hline 1. Bruto plaća (u eurima) & 48.109 & 64.146 & 80.182 & 64.146 \\
\hline 2. Doprinosi poslodavca & 4.405 & 5.751 & 7.267 & 5.751 \\
\hline 3. Doprinosi posloprimaca & 6.339 & 8.453 & 12.275 & 9.689 \\
\hline \multicolumn{5}{|l|}{ 4. Troškovi vezani uz rad } \\
\hline 5. Olakšice & 3.590 & 4.825 & 6.003 & 4.825 \\
\hline 6. Dohodak & 46.328 & 62.258 & 77.457 & 62.258 \\
\hline \multicolumn{5}{|l|}{ 7. Osobni odbitak } \\
\hline 8. Porezna osnovica & 46.328 & 62.258 & 77.457 & 62.258 \\
\hline 9. Porez na dohodak & 8.083 & 9.015 & 10.478 & 9.015 \\
\hline 10. Umanjenje poreza & 761 & 1.296 & 1.467 & 1.064 \\
\hline 11.Porez nakon umanjenja & 7.322 & 7.719 & 9.011 & 7.951 \\
\hline \multicolumn{5}{|l|}{ 12. Lokalni porezi } \\
\hline 13. Ukupno porezi & 7.322 & 7.719 & 9.011 & 7.951 \\
\hline $\begin{array}{l}\text { 14. Novčane naknade za } \\
\text { obitelj }\end{array}$ & 1.880 & 1.861 & 1.861 & 0 \\
\hline 15. Neto plaća & 36.328 & 49.835 & 60.757 & 46.505 \\
\hline 16. Trošak rada & 52.514 & 69.897 & 87.449 & 69.897 \\
\hline 17. Ukupno porezi i doprinosi & 18.066 & 21.923 & 28.553 & 23.391 \\
\hline $\begin{array}{l}\text { 18. Neto prosječna porezna } \\
\text { stopa }(\%)\end{array}$ & 24,5 & 22,3 & 24,2 & 27,5 \\
\hline $\begin{array}{l}\text { 19. Neto prosječni porezni } \\
\text { klin }(\%)\end{array}$ & 30,8 & 28,7 & 30,5 & 33,5 \\
\hline
\end{tabular}

Izvor: autoričini izračuni na temelju OECD-a (2014.). 